\title{
Review \\ Conserved and Distinct Elements of Phagocytosis in Human and C. elegans
}

\author{
Szilvia Lukácsi ${ }^{1} @$, Zsolt Farkas ${ }^{2}$, Éva Saskői ${ }^{2}$, Zsuzsa Bajtay ${ }^{1,3,+}$ and Krisztina Takács-Vellai ${ }^{2, *, \dagger}$ \\ 1 MTA-ELTE Immunology Research Group, Eötvös Loránd Research Network (ELKH), \\ Eötvös Loránd University, Pázmány Péter s. 1/C, 1117 Budapest, Hungary; \\ lukacsisz@student.elte.hu (S.L.); bajtay.zsuzsanna@ttk.elte.hu (Z.B.) \\ 2 Department of Biological Anthropology, Eötvös Loránd University, Pázmány Péter s. 1/C, \\ 1117 Budapest, Hungary; zsolt.farkas@ttk.elte.hu (Z.F.); eva.saskoi@ttk.elte.hu (É.S.) \\ 3 Department of Immunology, Eötvös Loránd University, Pázmány Péter s. 1/C, 1117 Budapest, Hungary \\ * Correspondence: krisztina.takacs@ttk.elte.hu \\ + These authors contributed equally to this work.
}

Citation: Lukácsi, S.; Farkas, Z.; Saskői, É.; Bajtay, Z.; Takács-Vellai, K. Conserved and Distinct Elements of Phagocytosis in Human and C. elegans. Int. J. Mol. Sci. 2021, 22, 8934. https://doi.org/10.3390/ ijms22168934

Academic Editor: Alexandre Mironov

Received: 29 June 2021

Accepted: 17 August 2021

Published: 19 August 2021

Publisher's Note: MDPI stays neutral with regard to jurisdictional claims in published maps and institutional affiliations.

Copyright: (c) 2021 by the authors. Licensee MDPI, Basel, Switzerland. This article is an open access article distributed under the terms and conditions of the Creative Commons Attribution (CC BY) license (https:// creativecommons.org/licenses/by/ $4.0 /)$.

\begin{abstract}
Endocytosis provides the cellular nutrition and homeostasis of organisms, but pathogens often take advantage of this entry point to infect host cells. This is counteracted by phagocytosis that plays a key role in the protection against invading microbes both during the initial engulfment of pathogens and in the clearance of infected cells. Phagocytic cells balance two vital functions: preventing the accumulation of cell corpses to avoid pathological inflammation and autoimmunity, whilst maintaining host defence. In this review, we compare elements of phagocytosis in mammals and the nematode Caenorhabditis elegans. Initial recognition of infection requires different mechanisms. In mammals, pattern recognition receptors bind pathogens directly, whereas activation of the innate immune response in the nematode rather relies on the detection of cellular damage. In contrast, molecules involved in efferocytosis-the engulfment and elimination of dying cells and cell debris-are highly conserved between the two species. Therefore, C. elegans is a powerful model to research mechanisms of the phagocytic machinery. Finally, we show that both mammalian and worm studies help to understand how the two phagocytic functions are interconnected: emerging data suggest the activation of innate immunity as a consequence of defective apoptotic cell clearance.
\end{abstract}

Keywords: endocytosis; phagocytosis; efferocytosis; apoptosis; Caenorhabditis elegans; pattern recognition receptors; innate immunity

\section{Introduction}

Phagocytosis and phagocytes were discovered by the Russian biologist Elia Metchnikoff in the late 19th century, and for this discovery, he was awarded the Nobel Prize in physiology and medicine in 1908, together with Paul Ehrlich. Phagocytic clearance plays a central role during normal tissue turnover, remodelling of embryonic tissues, the development of the immune system, and the resolution of inflammation [1].

Innate immunity is the evolutionary ancient part of the immune system that ensures immediate protection against invading microbes. Whereas the adaptive immune system emerged only during early vertebrate evolution, elements of innate immunity provide the protection of multicellular organisms in most invertebrate animals, including worms. These components might include physical barriers, secreted antimicrobial molecules or cells with a phagocytic capacity [2]. It is important to note, however, that even in vertebrates, adaptive immunity is strongly dependent on the activity of innate immune cells, and the co-evolution of the two arms formed the diverse and efficient immune system present in mammals.

The free-living nematode $C$. elegans coexists with a variety of pathogens such as bacteria, fungi and viruses in the soil. Pathogens can attack and infect the nematode via 
the cuticle and epidermis, the uterus, the rectum, or they might colonize the intestine. As C. elegans does not possess specialized immune cells, the above tissues also have a function in host defence. Additionally, the cuticle and the pharyngeal grinder often serve as mechanical barriers ensuring the first line of protection against microbes [3].

In humans the innate immune system consists of various cells, among them are neutrophils, monocytes, macrophages and immature dendritic cells known as professional phagocytes. These cells have a dual role in immunity: they are both eliminating the threat of non-self molecules and pathogens, and process self-antigens derived from engulfed apoptotic cells [4].

Tissue-resident phagocytes, e.g., macrophages in a non-inflamed environment, recognize, internalize and eliminate the cellular debris and apoptotic cells that are generated by normal development and tissue repair without inducing an inflammatory immune response. Neutrophil granulocytes are recruited in a large number to the sites of infection, where they phagocytose the pathogens, then undergo apoptosis. Apoptotic neutrophils are ingested by macrophages preventing the release of toxic molecules into the environment. Apoptotic cell recognition is mediated through the detection of molecules that are normally absent on live and healthy cells. The phagocytosis of apoptotic neutrophils induces anti-inflammatory cytokine synthesis by macrophages [5].

In contrast to this, the phagocytosis of microbes triggers a pro-inflammatory immune response. Microbial molecules including bacterial and fungal wall constituents, viral capsid components or pathogen-derived nucleotides are recognized by pattern recognition receptors (PRRs). The ligation of PRRs triggers pro-inflammatory and antimicrobial responses by inducing the activation of transcription factors, such as NF- $\mathrm{kB}$, or interferon regulatory factors which leads to the elimination of the invading organism [6].

Activated phagocytes produce large amounts of reactive species to eliminate pathogens. The two main families of these molecules are reactive oxygen (ROI) and nitrogen intermediates (RNI). ROI are generated by the activation of the NADPH oxidase (NOX) during the so-called oxidative burst. The superoxide radical $\left(\mathrm{O}_{2}{ }^{-}\right)$is formed as a product of the enzymatic activities of NOX and $\mathrm{O}_{2}{ }^{-}$is transformed by superoxide dismutase (SOD) enzymes to hydrogen peroxide $\left(\mathrm{H}_{2} \mathrm{O}_{2}\right)$, which can be further converted to the hydroxyl radical $\left(\mathrm{OH}^{-}\right)$. RNI molecules are produced during the conversion of L-arginine by the NO synthase (NOS) enzyme [7].

Phagocytes actively maintain an alkaline $\mathrm{pH}$ in their phagosomes via the activity of NOX, to kill microbial pathogens. The genetically determined lack of NOX in phagocytes leads to the development of chronic infections in various organs [8]. The redox homeostasis is maintained by antioxidant enzymes, including superoxide dismutase, catalase as well as non-enzymatic antioxidant molecules [9].

The insufficient regulation of reactive oxygen species leads to a state of oxidative stress. Harmful effects of ROI and RNI species are present both on the molecular (protein and lipid oxidation, DNA damage) and cellular level (effect on signal transduction, cell membrane functions and gene expression) $[10,11]$. Oxidative stress plays a crucial role in the development and maintenance of chronic inflammation and thus contributes to pathological conditions such as cardiovascular diseases, diabetes, neurodegenerative diseases or cancer [12]. Reactive oxidants affect all stages of the inflammatory response, including the release of molecules acting as endogenous danger signals, their sensing by innate immune receptors like TLRs and NLRs and the activation of signalling pathways initiating the immune response [13].

Phagocytosis provides crucial functions in immune defence: it is essential to clear pathogens and cellular debris in eukaryotic organisms [14]. The latter process, clearance of dying, apoptotic cells is essential in mammals to avoid pathological inflammation. The nematode Caenorhabditis elegans has been known as a powerful model to study cell death processes $[15,16]$. As cell death and cell clearance pathways are highly conserved between nematodes and mammals, the nematode has also emerged as a model organism to study the cause of diseases related to the misregulation of these processes [17]. In this review we 
focus on components and mechanisms of phagocytosis in mammals and in C. elegans. We show that genetic pathways involved in phagocytosis of cell corpses are highly conserved and studies on the worm contributed significantly to our understanding of apoptotic clearance mechanisms in humans. Our aim is also to compare how pathogen recognition and uptake is managed in the two systems: while in mammals pathogens are directly recognized and bound by a range of receptors of innate immune cells, in the worm, in the absence of direct pathogen recognition, the innate immune response is activated by cellular damage as a consequence of pathogen infection.

Interestingly, worms can avoid pathogen attacks by sensing metabolites of microbes via multiple sensory neurons, showing that innate immunity is regulated by the nervous system. Thus, the tiny worm can also be used as a model to study neuroimmunology, which is a dynamically developing field focusing on the connection of the nervous and immune systems. Finally, we summarize emerging data analyzing poorly understood interconnections between the two phagocytic functions, apoptotic clearance and initiation of the innate immune response against pathogens. Recent data obtained in both worms and mammals suggest activation of innate immunity as a consequence of defective apoptotic clearance [18].

\section{Forms of Endocytosis}

Various portals provide regulated entry into the cells, some of these mechanisms are constitutive, while others are based on receptor-mediated interactions. Macromolecules can enter the cell, enclosed into membrane-bound carriers, during the process of endocytosis. The known mechanisms of endocytosis differ in the mode of uptake and the intracellular pathway of the internalized cargo. These mechanisms include macropinocytosis, phagocytosis, clathrin-mediated and clathrin-independent endocytosis (Figure 1A) [19].

Cells can take up larger amounts of extracellular fluid and membrane-bound particles through the evolutionarily conserved macropinocytosis, with a vacuole size of 200-500 $\mathrm{nm}$ [20]. Macrophages and dendritic cells use this actin polymerisation driven method to constantly monitor their environment and collect peptides for antigen presentation [21].

Receptor-bound macromolecules and particles can be internalized through clathrinmediated endocytosis (CME). The ligand-receptor complexes are concentrated into patches in the cell membrane, where clathrin scaffold proteins and various adaptor molecules are recruited to form clathrin-coated pits (CCP) on the cytoplasmic surface of the plasma membrane. Then the membrane closes and a small clathrin-coated vesicle (CCV) arises, forming a 60-120 nm vacuole [22]. The internalization of endosomes requires the rearrangement of the actin cytoskeleton and the GTPase dynamin performs the last step of the process. After the clathrin-coated pit sinks into the cytoplasm, dynamin creates a "collar" that closes the vacuole. The clathrin-coated vesicle is then detached from the plasma membrane and the disassembly of the endocytic machinery begins $[23,24]$.

The many clathrin-independent pathways (CIE) are not as well characterized as CME, and they can be specified either by their characteristic cargo molecule or the coating of the vesicles. Lipid raft-associated molecules are often internalized in 50-100 nm large caveolin coated invaginations (caveolae), that are shuffled between the plasma membrane and early endosomes. Caveolae are most common in endothelial cells where they mediate transcellular transfer of serum proteins and nutrients from the bloodstream [25]. GPIanchored proteins (GPI-APs) are internalized into the GPI-AP enriched early endosomal compartment (GEEC) in a dynamin- and coating protein-independent manner [26]. Other CIE pathways include the endocytosis of the IL-2 Receptor (IL-2R), the Arf6- and the Flotillin-associated routes [25,27]. 
A

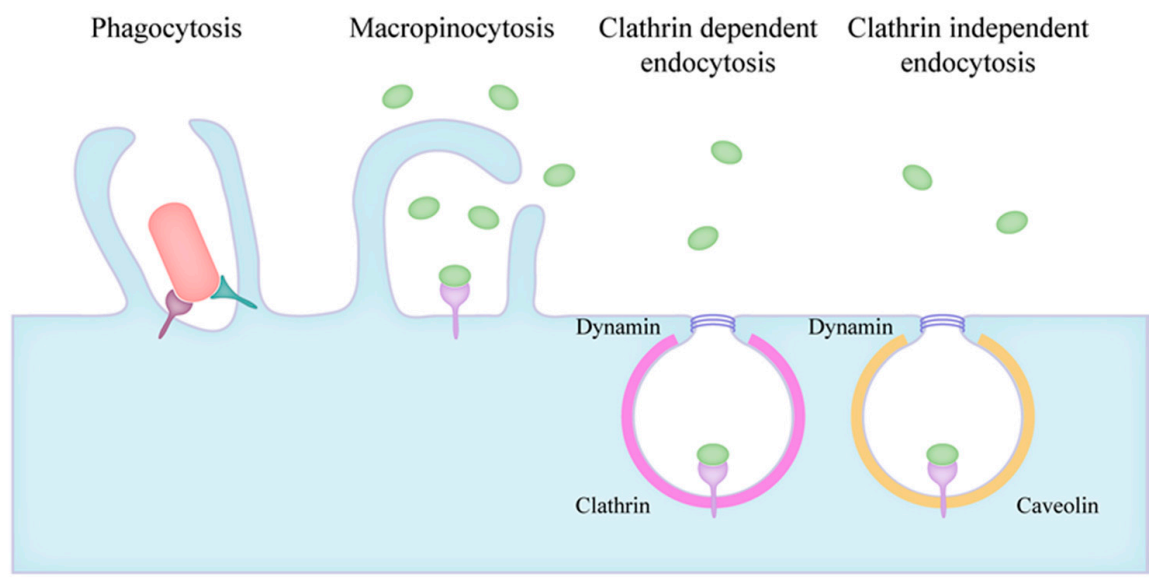

$\mathrm{B}$

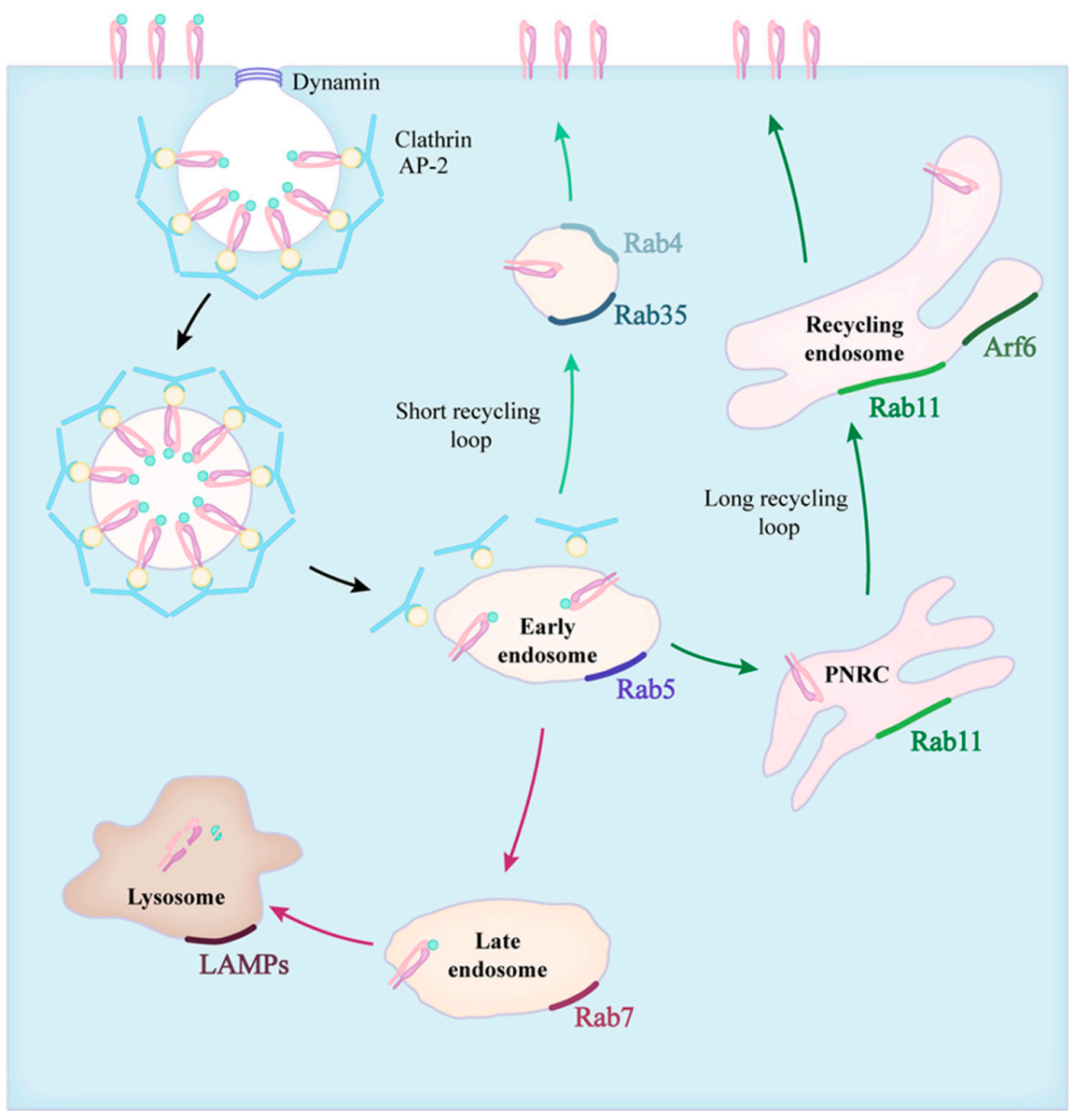

Figure 1. Forms of particle uptake and the endocytic routes. (A) The endocytic routes involve phagocytosis, macropinocytosis, clathrin mediated and clathrin independent endocytosis. (B) The fate of internalized particles is shown in the case of clathrin dependent endocytosis. Vesicles scissed from the plasma membrane quickly lose their clathrin coating and fuse with early endosomes (black arrows). Early endosomes transition into late endosomes, and in time, to lysosomes (red arrows). The recycling of receptors can occur via a short loop (green arrows), directly from early endosomes or through a long loop across the perinuclear recycling compartment (PNRC) and recycling endosomes (dark green arrows). The small GTPase Rab proteins characteristic for each stage are also indicated. 
Phagocytosis is defined as the specific receptor-induced uptake of particles larger than $500 \mathrm{~nm}$, like pathogens, dead cells or foreign bodies. This process induces actin filament assembly that causes the formation of pseudopods that surround the antigen. The main steps of phagocytosis are: pathogens binding to receptors, receptor clustering, phagocytic cup formation and phagosome sealing. Actin filaments support the plasma membrane as it zips tightly around the particle forming the phagocytic cup. The plasma membrane and internal membranes-recycling endosomes, late endosomes, and endoplasmic reticulum (ER) - might contribute to the organization of the phagocytic cup, in a so-called focal exocytosis process [28].

\section{Endocytic Route of Engulfed Particles and Receptor Recyclization}

After antigen uptake, the newly formed phagosome undergoes fusion events with various cytosolic organelles resulting in phagosome maturation. During the process of phagocytosis the phagosomal contents are digested, recycled or exocytosed [29]. The self and non-self discrimination determine the steps of phagosome maturation [30]. The presence of pathogens induces the production of reactive oxygen and nitrogen intermediates in the lysosomes of activated phagocytes, where the terminal degradation of the internalized pathogen takes place [29]. Both self and non-self molecules are continuously sampled and presented to $\mathrm{T}$ cells, strengthening self-tolerance or inducing a protective immune response. T cells recognize the antigens in peptide-MHC-I and -MHC-II complexes. MHC-II molecules accumulate within the internal membranes of endosomes, where peptide loading occurs [31].

The maturation of phagosomes is brought forward by the fusion with vesicles from the endosomal system, which is controlled by the Rab family of small GTPases [32]. The members of this family show a characteristic distribution, therefore they are often used as markers for the different stages of endosome maturation (Figure 1B). Firstly, phagosomes acquire Rab5 which promotes their fusion with early endosomes through the recruitment of Early Endosome Antigen 1 (EEA1) [33,34]. The size of the early endosomes is balanced by the fissure of Rab4-positive recycling vesicles directed at the plasma membrane [35-37]. The membrane composition of vesicles dynamically changes during maturation, and Rab5 is quickly exchanged for Rab7, which now mediates fusion with late endosomes, and later, lysosomes [38,39]. At this stage, the $\mathrm{pH}$ inside the vacuoles starts to decrease with the help of the vacuolar-type proton pump ATPases (V-ATPases), and this is followed by the accumulation of luminal hydrolytic enzymes [40]. Ubiquitinated proteins destined for degradation are often sorted from early to late endosomes and lysosomes via tubular invaginations that form intraluminal vacuoles (ILVs) in multivesicular bodies (MVBs) [41] Additionally, MVBs can also fuse with the plasma membrane that leads to the secretion of ILVs as exosomes, which are important elements of intercellular communication [42]. As the final step, the phagosome fuses with lysosomes, creating the phagolysosome, characterized by lysosome-associated membrane proteins (LAMPs) and a strongly acidic $\mathrm{pH}$ as low as 4.5. The acidic milieu of the phagolysosome activates the acidic protease cathepsins, which cleave the phagocytosed proteins into the smaller peptides necessary for antigen presentation on MHC complexes [43]. The recruitment of the NADPH oxidase complex also contributes to the elimination of ingested microbes through the production of reactive oxygen species [44].

The acidification, enzymatic activity and subsequent protein degradation are tightly regulated and often influenced by the activation and differentiation status of the antigenpresenting cells. For example, the IL-4/IL-13 induced maturation of macrophages (M2 or alternative phenotype) increases proteolytic activity while decreasing NADPH activity, developing a phagolysosome environment for quick protein degradation during tissue repair and wound healing. In contrast, LPS/IFN $\gamma$ stimulated (M1) macrophages produce a higher amount of reactive oxygen species for the effective elimination of pathogens [45], and the lower acidity and proteolytic capacity helps to retain peptides for antigen presentation [46,47]. In the case of dendritic cells, Delamarre et al. showed that their lysosomes 
contained fewer proteolytic enzymes, resulting in a slower degradation and the retention of antigens in the lymph nodes, which is crucial for an effective antigen presentation [48,49]. These observations highlight a cell type-specific regulation of phagocytosis and the endocytic pathway, to better suit the distinctive functions of antigen-presenting cells.

The availability of receptors is regulated by continuous receptor trafficking, which can occur via distinct routes [50]. Instead of degradation, they are recycled back to the cell membrane, extending the lifetime of these proteins [51]. These recycling routes are most explored in the case of the transferrin receptor (TfnR) and integrins. The TfnR, $\alpha_{V} \beta_{3}$ - and inactive $\beta_{1}$-integrins were shown to cycle through a short, Rab4-dependent pathway, where these receptors are quickly returned to the plasma membrane from the early endosomes $[36,52,53]$. In the Rab11-dependent long loop, described both for TfnR and $\beta_{1}$-integrins, receptors go through the perinuclear recycling compartment (PNRC) before returning to the cell surface [54,55]. Other small GTPases, like Rab35 and Arf6 (ADP-ribosylation factor 6) were also implicated in the return of receptors to the cell surface [55-57]. The fast recycling of integrins and phagocytic receptors grants the possibility for continuous ECM and ligand engagement, indispensable for cell migration and pathogen elimination.

Endocytosis is a highly conserved process among metazoans, thus most of the proteins involved in the endocytic trafficking in Caenorhabditis elegans possess the same name (ARF-6, RABs, etc.) and function as their human orthologs. Therefore, the nematode has been used early on as a model to monitor this process. Studies in C. elegans revealed various roles of membrane trafficking in development and physiology, and provided significant data at the molecular level of several mechanisms, including vesicle budding, membrane fission and fusion and cargo sorting [58]. As this organism is suitable for fast and efficient high throughput screens, plenty of studies identified new endocytosisrelated genes, like $c d c-42$ (Cell Division Cycle related) and par-6 (abnormal embryonic PARtitioning of cytoplasm) [59]. Genetic analysis in coelomocytes, cells specialized for fluid uptake, also revealed a role for cup-5 (Coelomocyte UPtake-defective, homologue of human mucolipin-1) in lysosomal function [60].

\section{Phagocytic Receptors and Pathogen Recognition}

\subsection{Pattern Recognition and Opsonic Receptors in Mammals}

Innate immune cells populate the possible entry points in the body and provide the first line of defence against invading pathogens. These cells utilize a range of receptors to quickly engage, capture and internalize their targets (Table 1). Pattern recognition receptors (PRRs) bind the pathogens directly via pathogen-associated molecular patterns (PAMPs), while complement or IgG opsonized targets are recognized by complementand Fc-receptors, significantly increasing the efficiency of phagocytosis [61]. Additionally, these cells have receptors dedicated to sensing the signs of danger, the anaphylatoxic complement fragments C3a and C5a or chemokines produced by resident cells in inflamed tissues [62,63]. These receptors have an important role in initiating the immune response by promoting leukocyte recruitment, enhanced phagocytosis and the release of reactive oxygen species $[64,65]$.

Pattern recognition receptors can be classified into several major families, but not all of them participate in particle internalization. Those that directly do not participate in phagocytosis modulate the immune response through signalling events. Toll-like receptors (TLRs) are transmembrane proteins found both intracellularly and on the cell surface, they recognise many bacterial, viral or fungal structures and danger signals from the host cells [66]. The intracellular NOD-like receptors (NLRs) recognise bacterial and fungal wall components and they have an important role in the induction of inflammation. Some NLRs are constituents of inflammasomes, where they trigger the activation of the proinflammatory cytokines IL-1 $\beta$ and IL-18 upon pathogen encounter [67]. The family of RIGlike receptors (RLRs) represents cytosolic receptors that bind viral nucleotides and elicit an inflammatory and antiviral response through the induction of type I IFN production [68]. 
C-type lectins (CLRs) are known to bind glycans through their carbohydrate recognition domain (CRD), mostly in a $\mathrm{Ca}^{2+}$ dependent manner, and with diverse structural and ligand binding features they recognise a wide range of pathogens [69]. Several CLRs were shown to be directly involved in the phagocytosis of microbes, while others might only help endocytosis through cell activation or ligand tethering.

The CLR family contains several phagocytic receptors: Dectin-1 provides anti-fungal immunity via the recognition and phagocytosis of $\beta$-glucan containing fungi-for example, Aspergillus fumigatus, Candida albicans or Pneumocystis [70,71], and it also participates in the binding of Mycobacterium and Leishmania species [72,73]. The signalling through dectin- 1 induces cytokine and ROS production and regulates the release of NETs in neutrophils [74]. Dectin-2 recognises the mannose components of bacterial and fungal cell walls found in C. albicans, Saccharomyces, Microsporum audouinii, Trichophyton rubrum and Mycobacterium tuberculosis [75-77]. The priming of dectin-2 is indispensable for an effective anti-fungal response, as it was shown to promote cytokine production and Th17 differentiation after C. albicans ligation [78]. Mincle (Macrophage-inducible C-type lectin) binds glycolipids on pathogens like Mycobacterium, Malassezia, Streptococcus pneumoniae and Klebsiella pneumoniae or lipid-based damaged self molecules, helping in the maintenance of tissue homeostasis [79-83]. Mincle was found to be in a functional complex with another CLR, namely MCL (Macrophage C-type lectin), and they use FceRI $\gamma$ for signalisation. Mincle and MCL are both receptors for the mycobacterial cord factor TDM (trehalose-dimycolate) [84,85], and the association of these molecules enhances phagocytic capacity [86].

Many C-type lectins were described as a receptor for the Human Immunodeficiency Virus (HIV), which are used to infect cells or transmit the virus to interacting partners. The Dendritic Dell-Specific Intercellular adhesion molecule-3 Grabbing Non-integrin (DC-SIGN) binds highly mannosylated and fucoslyated glycoproteins, which are abundantly expressed by many pathogens, like Mycobacterium tuberculosis, Helicobacter pylori, Leishmania mexicana, and Schistosoma mansoni $[87,88]$. DC-SIGN also binds many other viruses, for example, Dengue virus, Ebola virus, SARS, Hepatitis C virus (HCV) and cytomegalovirus (CMV), which often utilize this connection to enter DCs [89-93]. The binding of HIV-1 to DC-SIGN enhances the trans-infection of $\mathrm{CD}^{+} \mathrm{T}$ cells that come in contact with the infected DCs migrating to the lymph nodes [94,95]. The next receptor worth mentioning is the DC Immunoreceptor (DCIR), also specific for fucose and mannose containing glycans, and with the ability to bind HIV-1, this receptor similarly promotes virus dissemination $[96,97]$. On macrophages, the receptor responsible for the transmission of HIV and Dengue virus was shown to be the Macrophage Mannose Receptor (MMR) [98,99]. MMR recognizes mannose, fucose, and GlcNAc residues, found in many fungal or bacterial walls and virus envelopes [100,101]. The phagocytic internalization mediated by MMR was demonstrated in the case of Mycobacterium tuberculosis and Francisella tularensis [102,103]. Langerin is a trimeric receptor expressed on Langerhans cells, and was shown to recognize several glycoprotein ligands, including mannosylated and sulfated glycans [104,105], fungal $\beta$-glucans in the wall of several Candida and Saccharomyces species [106] and viral envelope proteins of HIV-1 and measles virus $[107,108]$. The internalization and digestion of particles through langerin were proven in the case of a mannosylated glycoprotein [109] and HIV-1 particles [107]. In contrast to DC-SIGN, the langerin-mediated uptake of HIV-1 results in the degradation of the virus inside the Birbeck granules of Langerhans cells, preventing its transmission to T cells [107].

The many members of the scavenger receptor family contribute to the elimination of non-self and altered self molecules by various functions and a wide spectrum of ligands. Some of them were also indicated in the recognition and engulfment of apoptotic cells [110]. Based on the latest attempt at creating a consensus nomenclature for scavenger receptors, 12 classes (A-L) were distinguished based on structural features, a full list and characterization of these molecules were reviewed by PrabhuDas et al. [111]. 
The first discovered Class A receptors entail the Macrophage Scavenger Receptor (MSR1, SR-A1) and the Macrophage Receptor with Collagenous Structure (MARCO, SRA6). They are characterized by an $\alpha$-helical coiled-coil, a collagenous, and a C-terminal scavenger receptor cysteine-rich (SRCR) domain [112]. Their ligands include the modified or oxidized, but not native LDL, and Gram-positive and -negative bacterial wall constituents like lipoteichoic acids and lipid A [113-116]. MARCO is predominantly expressed on macrophages in the lungs and in the spleen where its main function is the clearance of pathogens $[117,118]$.

One of the most studied scavenger receptors is CD36, representing Class B molecules, with a structure of two transmembrane domains connected by an extracellular loop [119]. It recognizes oxidized LDL, $\beta$-amyloids and polyanionic ligands of many bacteria [120-122] and cooperates with $\alpha_{\mathrm{v}} \beta_{3}$ and $\alpha_{\mathrm{v}} \beta_{5}$ in the elimination of apoptotic cells [123,124].

The F Class includes SCARF-1 (Scavenger Receptor Class F Member 1, SR-F1), and MEGF10 (Multiple EGF Like Domains 10, SR-F2), with an extracellular region built of EGF-like repeats [125]. SCARF-1 binds bacterial and fungal pathogens and heat-shock proteins $[126,127]$ and similarly to its C. elegans ortholog CED-1, it is involved in the engulfment of apoptotic cells [128]. MEGF10 binds both $\beta$-amyloids and C1q on apoptotic cells in the brain, indicating a possible role in the pathogenesis of neurological disorders $[129,130]$.

The Class H Stabilin-1 and Stabilin-2 consist of fasciclin, EGF-like, and lamin-type EGFlike domains (FEEL). Both receptors were indicated in the PtdSer mediated phagocytosis of apoptotic cells [131,132]. Additionally, Stabilin-1 was also shown to bind Gram-positive and -negative bacterial ligands [133], whereas Stabilin-2 is important in the turnover of hyaluronic acid and chondroitin sulphate, and it interacts with $\alpha_{\mathrm{v}} \beta_{5}$ to promote the engulfment of damaged erythrocytes $[134,135]$.

The second branch of pathogen clearance is opsonophagocytosis. This process utilizes the immediate deposition of complement fragments on microbial surfaces, and later on, the binding of specific antibodies. Antigens opsonised with complement fragments and immunoglobulins become available for uptake via complement- and Fc-receptors, enhancing phagocytic capacity, or in some cases, it can provide the pathogens the opportunity to infect host cells [136]. The activation of the complement cascade results in the cleavage of $\mathrm{C} 3$ and $\mathrm{C} 4$ molecules, which generates the ligands for complement receptors: $\mathrm{C} 3 \mathrm{~b}$ and $\mathrm{C} 4 \mathrm{~b}$ for CR1, iC3b for CR3 and CR4, and CRIg binds both $\mathrm{C} 3 \mathrm{~b}$ and $\mathrm{iC} 3 \mathrm{~b}$. The binding site of CRIg on $\mathrm{iC} 3 \mathrm{~b}$ and C3b does not overlap with the residues recognized by CR1, CR3 or CR4, thus providing the possibility for cooperation between these receptors [137].

CR1 is a single chain transmembrane glycoprotein composed of Short Consensus Repeat domains (SCRs). This receptor is involved in the clearance of complement opsonized pathogens and immune complexes (ICs) from blood. Red blood cells bind complementcontaining ICs via CR1, then deliver them to the liver or spleen for elimination [138]. CR1 was shown to be a receptor for Epstein-Barr virus (EBV), opsonized HIV and bacteria, often in cooperation with CR3 [139-141].

CRIg is expressed by resident macrophage subsets, among which the most studied are Kupffer cells in the liver. It is proposed that Kupffer cells quickly clear circulating pathogens from the blood in an anti-inflammatory manner, without the involvement of other PRRs and CRs, until pathogen numbers rise above a limit [137]. The importance of CRIg in the rapid internalization of pathogens was proven in the case of complement opsonized Adenovirus particles, Staphylococcus aureus, Listeria monocytogenes and Candida albicans [142-144].

The $\beta_{2}$-integrins CR3 and CR4 are known to play an essential role in cell motility and the elimination of pathogens, tumour- and apoptotic cells via phagocytosis [145]. The many ligands described for these receptors, including complement proteins, ECM components and adhesion molecules, are all recognised by the major ligand-binding site in the $\alpha \mathrm{I}$-domain [146]. The $\beta$-glucan components of fungal cells are recognized by a separate lectin site in CR3, located C-terminally from the I-domain [147,148]. An also I-domain independent binding site for bacterial lipopolysaccharides was shown as well, in both CR3 and CR4 $[149,150]$. Due to their structural similarities, the two receptors are often 
assumed to have the same functions, but depending on the cell type and microbe used in the experiments, there can be differences in their pathogen recognition. Both receptors were implicated in the uptake and killing of Escherichia coli and Mycobacterium tuberculosis, but in the case of Staphylococcus aureus only CR3 participated in the phagocytosis [151-154]. The list of pathogens interacting with complement receptors has been previously reviewed by our group [136].

Table 1. Phagocytic receptors in mammals.

\begin{tabular}{|c|c|c|}
\hline Receptors & Recognized Molecules & Distribution \\
\hline \multicolumn{3}{|l|}{ Pattern recognition receptors } \\
\hline CD14 & LPS [155] & $\mathrm{Mo}, \mathrm{M} \varphi, \mathrm{DC}, \mathrm{Neu}$ \\
\hline \multicolumn{3}{|l|}{ C-type lectins } \\
\hline langerin (CD207) & $\begin{array}{c}\text { sulfated and mannosylated glycans }[104,105] \\
\text { fungal } \beta \text {-glucans }[106], \text { viral envelope } \\
\text { glycoproteins }[107,108]\end{array}$ & $\mathrm{LC}$ \\
\hline DC-SIGN (CD209) & $\begin{array}{l}\text { fucosylated-, oligomannose- and N-glycans [87], } \\
\text { HIV-1 [94] }\end{array}$ & DC \\
\hline Dectin-1 (CD369) & fungal $\beta$-glucans $[70,71]$ & Mo, M $\varphi$, DC, B cell, PMN \\
\hline Dectin-2 & $\begin{array}{l}\text { Leishmania [72], Mycobacterium } \\
\text { mannose in fungal and } \\
\text { bacterial cell walls [75-77] }\end{array}$ & $\mathrm{Mo}, \mathrm{M} \varphi, \mathrm{DC}, \mathrm{Neu}, \mathrm{B}$ cell \\
\hline MMR (CD206) & mannose, fucose, GlcNAc $[100,101]$ & $\mathrm{M} \varphi, \mathrm{DC}$ \\
\hline Mincle-MCL & fungal and bacterial glycolipids $[81,82]$ & $\mathrm{Mo}, \mathrm{M} \varphi, \mathrm{DC}, \mathrm{B}$ cell \\
\hline MGL & terminal GalNAc residues [156] & DC \\
\hline DCIR & $\begin{array}{l}\text { fucose and mannose containing glycans, } \\
\text { HIV-1 }[96,97]\end{array}$ & $\mathrm{Mo}, \mathrm{M} \varphi, \mathrm{DC}, \mathrm{PMN}$ \\
\hline \multicolumn{3}{|l|}{ Scavenger receptors } \\
\hline MSR1 & modified LDL, $\beta$-amyloid, heat-shock proteins & $\mathrm{Mo}, \mathrm{M} \varphi, \mathrm{DC}, \mathrm{MC}$ \\
\hline (SR-A1) & {$[113,114]$, bacterial wall components $[115,116]$} & \\
\hline MARCO (SR-A6) & LPS, acetylated LDL $[157,158]$ & $\mathrm{M} \varphi$ \\
\hline $\begin{array}{c}\text { CD36 } \\
\text { (SR-B2) }\end{array}$ & $\begin{array}{c}\text { oxidized LDL, } \beta \text {-amyloids [120], polyanionic } \\
\text { bacterial ligands [122], apoptotic cells [123] }\end{array}$ & Mo, $\mathrm{M} \varphi$, platelets \\
\hline SCARF-1 (SR-F1) & $\begin{array}{l}\text { bacterial, fungal pathogens, heat-shock proteins, } \\
\text { apoptotic cells [126-128] }\end{array}$ & $\mathrm{M} \varphi, \mathrm{DC}$, endothelial cells \\
\hline MEGF10 (SR-F2) & C1q on apoptotic cells, $\beta$-amyloids $[129,130]$ & astrocytes \\
\hline $\begin{array}{l}\text { Stabilin-1 } \\
\text { (SR-H1) }\end{array}$ & PtdSer [131], bacterial components [133] & $\begin{array}{l}\text { macrophages, } \\
\text { endothelial cells }\end{array}$ \\
\hline $\begin{array}{c}\text { Stabilin-2 } \\
\text { (SR-H2) }\end{array}$ & PtdSer [132], hyaluronic acid [134], heparin [159] & sinusoidal endothelial cells. \\
\hline \multicolumn{3}{|l|}{ Complement receptors } \\
\hline $\begin{array}{c}\text { CR1 } \\
(\mathrm{CD} 35)\end{array}$ & C3b, C4b [160], EBV [139], MBL, C1q [161] & $\begin{array}{c}\text { Mo, } \mathrm{M} \varphi, \mathrm{DC}, \mathrm{PMN}, \mathrm{NK}, \mathrm{B} \text { cell, } \mathrm{T} \text { cell } \\
\text { subsets, RBC, FDC }\end{array}$ \\
\hline CRIg & $\mathrm{C} 3 \mathrm{~b}, \mathrm{iC} 3 \mathrm{~b}[143]$ & $\begin{array}{l}\text { KC and tissue-resident } \\
\text { macrophage subsets }\end{array}$ \\
\hline $\mathrm{CR} 3\left(\alpha_{\mathrm{M}} \beta_{2}, \mathrm{CD} 11 \mathrm{~b} / \mathrm{CD} 18\right)$ & $\begin{array}{c}\text { iC3b [146], FH, FHR-1 [162], } \\
\beta \text {-glucan [148], LPS [149] }\end{array}$ & $\begin{array}{l}\text { Mo, M } \varphi, \text { DC, PMN, NK, } \\
\text { lymphocyte subsets }\end{array}$ \\
\hline $\mathrm{CR} 4\left(\alpha_{X} \beta_{2}, \mathrm{CD} 11 \mathrm{c} / \mathrm{CD} 18\right)$ & iC3b [163], FH [164], LPS [150] & $\begin{array}{l}\text { Mo, } \mathrm{M} \varphi, \mathrm{DC}, \mathrm{PMN}, \mathrm{NK} \\
\text { lymphocyte subsets }\end{array}$ \\
\hline
\end{tabular}

Abbreviations: DC: dendritic cell; FDC: follicular dendritic cell; FH: factor H; FHR: factor H related protein; KC: Kupffer cell; LC: Langerhans cell; LDL: low-density lipoprotein; LPS: lipopolysaccharide; MC: mast cell; MFG-E8: milk fat globule-epidermal growth factor 8; Mo: monocyte; M $\varphi$ : macrophage; Neu: neutrophil granulocyte; PMN: polymorphonuclear cells; PtdSer: phosphatidylserine; RBC: red blood cell.

\subsection{Innate Immunity and the Lack of Direct Pathogen Recognition in C. elegans}

Innate immunity is the evolutionarily ancient part of the immune system that is already present in invertebrates. It is important to note however that in C. elegans, the engulfment and elimination of dying cells are not mediated by professional phagocytes, but instead, they are performed by neighbouring cells, which can be hypodermal, muscle, intestinal and gonadal sheath cells $[165,166]$. 
In the nematode, the innate immune system is activated through the recognition of cell damage via damage-associated molecular patterns (DAMPs) that can be both pathogeninduced or environmental in origin. Abiotic stress factors, for example, altered temperature or changes in osmolarity, provoke an unfolded protein response or result in the accumulation of reactive oxygen species. Recent data show that there is an interplay between signalling pathways mediating stress responses and the activation of innate immunity, as perturbations of basic cellular mechanisms, such as translation or mitochondrial function also result in cellular damage [3]. Thus, the above process, which is also known as surveillance immunity [167], only allows the worm to fight against microbes after the infection has already taken place and the damage has to be cured.

Following the recognition of DAMPs, downstream signal transduction pathways are activated, which leads to changes in the expression of genes encoding antimicrobial peptides (AMPs) and other secreted signals mediating the effector mechanisms of the innate immune response. Specifically, infection recognition activates evolutionarily conserved signal transduction ways, including the mitogen-activated protein kinase (MAPK) signalling, the DAF-2 (Abnormal Dauer Formation-2)/insulin-like receptor or the DPP/BMP Like-1 (DBL-1)/transforming growth factor $\beta$ (TGF- $\beta$ ) pathways [3]. The stress-activated MAPKs, JNK (c-Jun $N$-terminal kinase) and p38, play a crucial role in the regulation of both innate immune defence and abiotic stress responses in mammals [168,169]. The C. elegans p38 MAPK homologue PMK-1 (p38 MAP Kinase Family-1) and its upstream activating kinases SEK-1 (SAP/ERK kinase-1 as MAPKK/MAPK kinase) and NSY-1 (Neuronal Symmetry-1 as MAPKKK/MAPK kinase kinase) were first shown to function in host resistance to Pseudomonas aeruginosa in the intestine [170,171]. Later studies revealed the central role of this MAPK cascade in defence mechanisms against a broad range of other bacterial and fungal pathogens in the intestine and epidermis [172-176]. KGB-1 (Kinase GLH Binding-1), the worm JNK-like MAPK homologue, is involved in the protection from bacterial pore-forming toxins [177]. The third MAPK module is also implicated in host defence mechanisms in the worm. Together with the Ras homologue LET-60 (LEThal-60), LIN-45 (abnormal cell LINeage-45, homologous to Raf), MEK-2 (MAP kinase kinase-2) and MPK-1 (MAP Kinase-1) are required to induce the tail-swelling response against Microbacterium nematophilum in rectal epithelial cells [178].

Despite similarities in downstream signalling cascades, initial pathogen recognition does not function in a conserved manner between C. elegans and mammals. Many pattern recognition receptors found in other species are missing in the worm [179] (for example, NLRs or peptidoglycan recognizing receptors), and although the worm genome encodes a large set of galectins and C-type lectins [180], their role in pathogen recognition has not been confirmed. The nematode displays a sole Toll-like receptor homologue TOL-1, but this molecule does not function directly in the recognition of pathogens $[181,182]$. Instead, it is involved in pathogen-avoidance behaviour by promoting the development and function of chemosensory BAG neurons, which monitor the metabolic activity of microbes [183]. In contrast, TIR-1 (Toll and Interleukin-1 Receptor domain protein-1), orthologous to the human TIR domain-containing SARM (sterile $\alpha$ and armadillo motif-containing protein) $[181,184]$, is directly involved in innate immune response as it is required for PMK-1 activation upstream of NSY-1 in host resistance against many pathogens [185].

According to Matzinger's danger theory, the innate immune system is activated not only by pathogen-associated molecular patterns (PAMPs) but also by tissue-derived danger signals, called damage-associated molecular patterns (DAMPs). This is relevant because C. elegans lacks PRRs, implying that the innate immune response is also triggered by cellular damage [186,187]. Indeed, Pujol et al. showed that injuries of the epidermis caused by a needle result in PMK-1 activation reminiscent of that observed after a fungal infection [188]. A similar effect was detected in the intestine where the direct cellular damage caused by bacterial pore-forming toxins also activated PMK-1 [177,189].

A recent study conducted by Zugasti et al., investigating the regulation and induction of antimicrobial peptides (AMPs) in the epidermis, demonstrated how pathogen infection 
caused by Drechmeria coniospora and direct wounding of the epidermis are connected [190]. The pathogen's conidia adhere to the worm's cuticle, penetrate it, disrupting epidermal integrity. They found that a G protein-coupled receptor (GPCR), DCAR-1 (DihydroCaffeic Acid Receptor-1) is activated in response to physical injury of the epidermis caused by Drechmeria infection. Downstream of DCAR- 1 the signal is mediated by G $\alpha$ and G $\beta$ encoding genes gpa-12 (G protein alpha subunit-12) and rack-1 (RACK-1 (mammalian Receptor of Activated C Kinase) homolog) [191], which activate tpa-1 (tetradecanoyl phorbol acetate resistant-1), homologous to the mammalian protein kinase $C \delta(\mathrm{PKC} \delta)$. Subsequently, TPA-1 acts through the p38 MAPK pathway (TIR-1/NSY-1/SEK-1/PMK-1) and involves the STAT-like transcription factor STA-2 (STAT Transcription Family 2) [192] to regulate a cluster of $n l p$ (neuropeptide-like protein) genes such as $n l p-29$, encoding antimicrobial peptides [181,193]. Zugasti et al. identified an endogenous ligand of DCAR-1, hydroxyphenyllactic acid (HPLA), a tyrosine derivative whose level is elevated upon fungal infection and direct wounding of the epidermis. It remains to be solved whether the pathogen $D$. coniospora directly increases HPLA levels or the elevated level of the tyrosine derivative is the response of the worm for the physical damage in the epidermis upon infection. Both scenarios support the idea that HPLA acts as a DAMP for the nematode [190].

\section{Phagocytosis of Apoptotic Cells}

\subsection{Apoptotic Engulfment in Mammals}

The efficient clearance of senescent and dying cells during ontogenesis and aging is crucial for the maintenance of tissue homeostasis. The phagocytosis of apoptotic cells, termed efferocytosis, is considered to be immunologically silent or even immune-suppressive, with tissue-resident macrophages releasing anti-inflammatory mediators and dendritic cells inducing the differentiation of tolerogenic T cells after the uptake of apoptotic cells $[4,194,195]$.

Although cells undergoing apoptosis retain an intact plasma membrane, there are changes in the phospholipid composition in the outer leaflet that work as an "eat me" signal for phagocytes. The most well-known indicator of apoptosis is the exposure of phosphatidylserine (PtdSer) on the cell surface [196]. In healthy cells, this phospholipid is actively kept in the inner leaflet by lipid transporters called flippases [197]. The caspases present during apoptosis both disrupt the function of flippases maintaining the asymmetrical distribution of PtdSer and activate scramblase enzymes that catalyse the reverse translocation of this molecule [198,199].

PtdSer is either directly recognised or is bound to receptors on phagocytes through soluble bridging molecules (Figure 2, Table 2). A PtdSer receptor (PSR) was first described by Fadok et al. using a monoclonal antibody (mAb217) that bound to the surface of macrophages and inhibited the uptake of apoptotic bodies [200]. However, subsequent experiments trying to identify this receptor produced some contradictory data [201]. The protein encoded by the $p s r$ gene, later named JMJD6 (Jumonji domain-containing protein 6), was shown to be located in the nucleus, having an important function in embryonic development with a histone demethylase activity [202,203]. Thus, it is possible that the surface molecule responsible for the binding of apoptotic bodies is not identical to the product of the suspected evolutionarily conserved psr-1 gene.

The receptors of the TIM family (T cell immunoglobulin- and mucin-domain-containing molecule) mediate the recognition and/or uptake of apoptotic bodies in various cell types by directly binding PtdSer. All three human TIM proteins (TIM1, -3, -4) have been proven to bind PtdSer, but the internalization of particles can be cell type-specific. TIM1 functions on $\mathrm{T}_{\mathrm{h}}$ 2-cells as a costimulatory molecule [204] and it is upregulated in kidney epithelial cells after injury, allowing the engulfment of apoptotic bodies for tissue recovery [205]. TIM3 is expressed on $\mathrm{T}_{\mathrm{h}} 1$ cells and dendritic cells in humans, but the internalization of PtdSer containing apoptotic bodies was only observed in myeloid cells [206-208]. Presumably, the most efficient apoptotic cell receptor of this family is TIM4 that is expressed on dendritic cells and various tissue-resident macrophages, like peritoneal or liver Kupffer cells, providing clearance throughout the body [209-211]. 


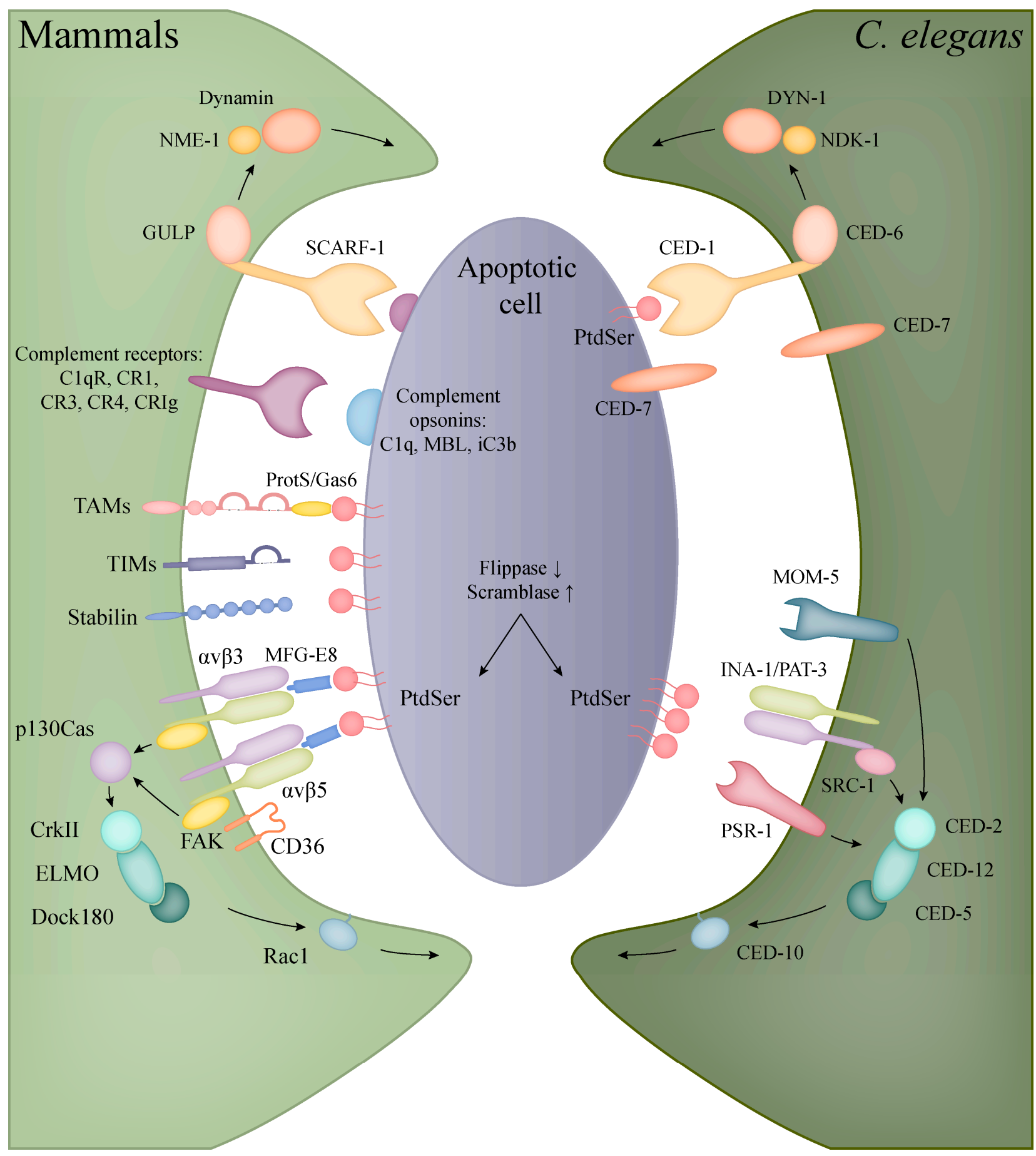

Figure 2. Recognition and engulfment of apoptotic cells in mammalian phagocytes and C. elegans. The evolutionarily conserved CED-1/CED-6/DYN-1 (corresponding to human SCARF-1/GULP/Dynamin) and CED-2/CED-5/CED-12/CED10 (in human: CrkII/Dock180/ELMO/Rac1) pathways are present in both C. elegans and mammals with the same functions in the clearance of apoptotic cells (orthologous molecules are indicated with the same colours). In mammals, however, a higher diversity can be observed in the recognition of apoptotic bodies, including the families of TIM and TAM proteins, complement and scavenger receptors. 
Table 2. Molecules involved in the phagocytosis of apoptotic cells in human and C. elegans.

\begin{tabular}{ccc}
\hline Human Protein & Function & C. elegans Protein \\
\hline ATP8A2 & P4-type ATPase/flippase & TAT-1 \\
XKR8 & scramblase & CED-1 \\
SCARF1, MEGF10 and 11, LRP1 (CD91), Jedi-1 & phagocytic receptor & CED-6 \\
GULP & adaptor & NDK-1 \\
NME1 & nucleoside diphosphate kinase & DYN-1 \\
Dynamin & large GTPase & CED-7 \\
ABCA1 and ABCA7 & ABC transporter & PSR-1 \\
JMJD6 (PSR?) & receptor & MOM-5 \\
FZD1 and 7 (Frizzled class receptor 1 and 7) & receptor & INA-1/PAT-3 \\
integrin $\alpha / \beta$ chain & receptor & SRC-1 \\
SRC & non-receptor tyrosine kinase & CED-2 \\
CrkII & adaptor & CED-12 \\
ELMO & adaptor & CED-5 \\
Dock180 & Rac GEF & CED-10 \\
Rac1 & Rho family GTPase & - \\
MFG-E8 & bridging between PtdSer and integrins & - \\
TIM1, 3, 4 & PtdSer receptor & -
\end{tabular}

The indirect binding of PtdSer can happen through the bridging molecules Protein $S$ and GAS6 (growth-arrest-specific 6) and their receptors, the tyrosine kinase TAMs (Tyro3, Axl, Mer) [212]. Protein S is synthetised mostly in liver hepatocytes and activates Tyro3 and Mer, but not Axl, whereas GAS6 acts as an agonist for all three TAM receptors [213]. The TAM receptors are expressed in both macrophages and dendritic cells, but Seitz et al. showed that DCs mainly rely on the functions of Axl and Tyro3, whereas macrophages use all three [214]. The signalling through TAMs contributes to tissue homeostasis via the inhibition of inflammatory responses in myeloid cells $[215,216]$.

Another group of soluble PtdSer-recognizing molecules includes MFG-E8 (milk fat globule-EGF factor 8 or lactadherin) and thrombospondin, which contain RGD motifs, thus connecting apoptotic cells to the integrins $\alpha_{\mathrm{V}} \beta_{3}$ and $\alpha_{\mathrm{v}} \beta_{5}[217,218]$. Both integrins were shown to cooperate with the scavenger receptor CD36 in the uptake of apoptotic cells $[124,219]$. The binding of apoptotic cells through these integrins initiates the phosphorylation of FAK and the recruitment of $\mathrm{p} 130^{\mathrm{Cas}}$ (Crk-associated SRC substrate), which connects to the evolutionary conserved CrkII-Dock180-ELMO-Rac1 pathway mediating the engulfment of the particles through actin polymerisation and phagocytic cup formation [220-222]. Other scavenger receptors are also known to participate in the elimination of apoptotic cells, the specific ligands and functions of this receptor family are detailed in Section 4.1.

The complement system also participates in the opsonization, recognition and elimination of apoptotic cells. The complement components C1q and MBL bind apoptotic and necrotic cells, enhancing their uptake by phagocytes and in the presence of serum, activating the classical and lectin pathway [223-225]. The activation of the alternative pathway by apoptotic cells was also proved by several studies, resulting in the deposition of C3 fragments and phagocytosis by the complement receptors CR1, CR3, CR4 and CRIg [226-228]. Opsonization with complement facilitates the quick and effective clearance of apoptotic cells without an inflammatory response, which is further supported by the immunosuppressive qualities of $\mathrm{C} 1 \mathrm{q}[229,230]$.

\subsection{Apoptotic Engulfment and Clearance in C. elegans}

Programmed cell death can be divided into three phases: the first is the specification of the cell destined to die, and the second is the killing phase, where the apoptotic pathway is activated and lastly the execution of cell death and dismantling. The last phase also 
includes the elimination of apoptotic bodies, where a specialized or neighbouring cell engulfs and removes the debris of the dying cell. The conserved genes involved in the core apoptotic pathway were first identified in C. elegans, for which the Nobel prize for Medicine was awarded to Sydney Brenner, John E. Sulston, and H. Robert Horvitz in 2002 [15,16]. The main characteristics and genetic pathways of apoptosis in C. elegans are detailed in this special issue published by E. Pourkarimi.

Phagocytosis of apoptotic corpses involves conserved pathways in the nematode (Table 2). The worm does not possess dedicated macrophages; instead, the neighbouring cells provide the phagocytic function. Similar to other organisms, the well-conserved PtdSer acts as the main signal of cell death or "eat-me" signal. The exposure of PtdSer in the worm during apoptosis is linked to the amino phospholipid translocase TAT-1 (Transbilayer Amphipath Transporter, ortholog of human flippase, ATPase phospholipid transporting 8A2, ATP8A2) and CED-8 (CEll Death abnormality 8, ortholog of human scramblase XKR8) function. In a living cell translocases actively transport PtdSer from the outer to the inner leaflet of the plasma membrane, but in an apoptotic cell, the inactivation of translocases and the activation of scramblases results in PtdSer accumulation on the cell surface [231]. After the recognition of an apoptotic cell, the activated receptors stimulate the extension of the engulfing cell's membrane and the rearrangement of the actin cytoskeleton. Consequently, the phagocytic cell develops pseudopods around the dying cell. Just as the pseudopods fuse, the newly formed phagosome separates from the plasma membrane [232].

Two main, partly overlapping and conserved signalling pathways control the engulfment of apoptotic cells in C. elegans [233]. One contains the phagocytic receptor CED-1 (human SCARF-1), the adaptor CED-6 (GULP), the ABC transporter CED-7 (ABCA) and the large GTPase DYN-1 (Dynamin2). The second path entails the CED-2 (CrkII), CED-5 (Dock180), CED-10 (Rac1), CED-12 (ELMO) proteins, the latter being the counterpart of the human Rac signalling. These two pathways partly converge at CED-10 involved in actin polymerisation, regulating the required cytoskeleton rearrangement for engulfment [234,235].

The first pathway is triggered by the phagocytic transmembrane receptor CED-1, which only appears on the surface of the engulfing cell. After ligand recognition, the amount of CED-1 increases in the engulfing cell's plasma membrane that is in contact with the neighbouring dead cell, initiating the formation of the phagocytic cup. The PtdSer driven activation of CED-1 triggers the subsequent members of the signalling cascade, resulting in the growth of pseudopods [236]. CED-7 has a dual role to mediate the eat-me signal, it is expressed in both the engulfed and the engulfing cell: CED-7 assists in the exposure of PtdSer and also helps CED-1 to capture the PtdSer signal [237]. Then the activated CED-1 signal is transmitted by CED-6, partly activating CED-10, but mostly triggers through DYN-1 that regulates the extension of the engulfing cell membrane [234].

DYN-1 is a large GTPase that has multiple roles related to membrane trafficking. During engulfment, the phagocytic cup is transiently enriched in DYN-1 that provides the surplus of membrane necessary for pseudopod extension by helping the recruitment of early endosomes and their fusion with the cell membrane [238]. Furthermore, it also mediates the last event in the engulfment process, namely the fission of phagosomes from the plasma membrane [23]. For these functions, DYN-1 requires high amounts of GTP, which is provided by NDK-1 (Nucleoside Diphosphate Kinase-1, ortholog of human NME1) [239]. It is important to note that both DYN-1 and NDK-1 are detected on the surface of early phagosomes, indicating that they also have roles in the early steps of phagosome maturation [238-240].

The second pathway has an equally important role in the engulfing process: next to the membrane extension detailed above, the rearrangement of actin cytoskeleton is also crucial for the internalization of apoptotic cells. The components of this pathway regulate CED-10 activation [241]. The pathway is triggered by the recognition of PtdSer by three different receptors: integrins, PSR- 1 and MOM-5. The core of this pathway is the CED-2/CED-5/CED-12 trio, which complex acts as the guanine nucleotide exchange factor 
(GEF) of CED-10. The first possible route to trigger this pathway is through the integrin consisting of two subunits: INA-1 (integrin alpha-1) and PAT-3 (Paralysed Arrest at Twofold, beta subunit) [242,243]. In this case, CED-2 connects to the integrin receptor through SRC-1 (SRC oncogene related) and recruits the other two members of its complex [242]. The other alpha subunit, PAT-2, might also have a role in recognising PtdSer, but the results published about the exact role of the PAT-2/PAT-3 heterodimer receptor in phagocytosis is controversial [244,245]. The next receptor that has an influence on this pathway is PSR1 (ortholog of human PSR, phosphatidyl serine receptor). CED-12 directly connects to this receptor and recruits the other two members of its complex upon activation [243]. Besides the above-mentioned two receptors, the Frizzled homolog MOM-5 (More Of MS 5) connects the Wnt signalling to the engulfment process, which also acts through the CED-2/CED-5/CED-12 complex [246].

Recently, a third pathway has been identified, revealing the important role of RAB-35 in the early steps of apoptotic cell phagocytosis. RAB- 35 is a multifunctional GTPase that plays important roles in phagocytosis, cytokinesis, apico-basal polarity, cell migration, neurite outgrowth, immune synapse, exosome release and pathogen hijacking [247]. During phagocytosis, RAB-35 localizes at the developing pseudopods, and later on early phagosomes, suggesting a function in early phagocytic events [248]. The Zhou laboratory identified a novel role for RAB-35: rab-35 mutants show a delay in apoptotic cell recognition, also rab-35 mutant phenotypes are enhanced in both ced-1 and ced-5 mutant backgrounds, which is further worsened in ced- 1 , rab-35, ced-5 triple mutants. As a conclusion, rab-35 functions in a third pathway in parallel to the ced-2/-5/-10/-12 and ced-1/-6/-7 pathways, and further genetic epistasis analysis indicates that rab-35 function is also linked to the integrin pathway [248].

\subsection{The Interconnection of Innate Immunity with Apoptotic Cell Clearance and the Nervous System}

Phagocytes perform a dual role in host defence as they are both responsible for removing apoptotic debris and initiating an innate immune response against pathogens. Despite its importance, the connection between these two functions is poorly understood. Recently it was shown in C. elegans that mutations in the genes involved in apoptotic cell clearance make them more resistant to the pathogenic bacteria Pseudomonas aeruginosa and Salmonella typhimurium [18]. The mutant worms showed an upregulation of the innate immune response genes, even in the absence of bacterial pathogens, and this response was actively regulated by the apoptotic cell clearance defects through the PMK-1 and MPK-1 pathways [18].

Similar observations were documented in mammals: inefficient removal of dead cells activates the innate immune system [249]. In DNaseII knockout mice, the DNA of apoptotic cells is not entirely degraded in lysosomes, which leads to the induction of an immune response and the development of chronic arthritis and anaemia [249]. In line with these data, the production of antibacterial peptides was observed both in C. elegans and Drosophila if apoptotic germ cells lacked DNaseII [250,251]. As there are some controversial data [252], further investigation is needed to precisely determine the relationship between the innate immune response and apoptotic cell clearance.

Interestingly, recent studies also suggest a neurological connection to immunity, as worms were proven to be able to avoid pathogen attacks through sensing microbes via their nervous system. Multiple sensory neurons and GPCRs are involved in the detection of specific molecules and the local fluctuations of oxygen and carbon dioxide levels generated by bacterial metabolism (reviewed in [253]). Thus, it is thought that the nervous system can regulate immunity in the nematode, in line with similar findings observed earlier in mammals [254-256]. C. elegans has only 302 neurons with detailed functional and morphological characterization available, and together with the knowledge of the entire synaptic wiring diagram, it can provide useful insights into the research of vertebrate neuroimmunology. 


\section{Discussion}

In mammals, phagocytosis plays a dual role in immune defence. Firstly, pathogens are recognized and internalized by professional phagocytes, initiating the first steps in the fight against infection and later on, antigen presentation that promotes the induction of an adaptive immune response. Secondly, phagocytosis also provides the means to eliminate dead cells or cell debris to support tissue remodelling and to avoid autoimmune reactions.

Phagocytosis is an evolutionarily ancient defence mechanism that is already present in invertebrates. In this review, we compared elements of phagocytosis in mammals and in the nematode Caenorhabditis elegans. Although the two species utilise different mechanisms in the initial recognition of pathogens, the process of apoptotic cell engulfment is highly conserved between worms and mammals, making C. elegans a well-recognized model organism to study cell death [16]. Not only are the genetic cascades of the core apoptotic machinery conserved between humans and worms, but many regulators of cell clearance have homologs in mammals [241]. As C. elegans is often used for large-scale drug screens in many biological aspects [257], conserved components of the phagocytic machinery potentially allow using the worm as a model to test drugs, which enhance or inhibit phagocytosis.

Although C. elegans lacks the diverse machinery and immunological memory of vertebrates, it has an innate immune defence system and responds to infection by activating the expression of antimicrobial peptides [3]. However, the recognition of pathogens differs in the worm compared to mammalian systems. In the absence of PRRs, DAMPs are recognized instead of PAMPs, and consequently, the innate immunity is activated by cellular damage, which can be the result of many abiotic stress factors as well.

Ever-growing evidence proves that the immune system does not function autonomously, but it is interconnected with many cellular processes to maintain homeostasis. For instance, the field of neuroimmunology has been dynamically developing during recent decades after the initial discoveries that connect the two systems, such as the presence of neuroendocrine hormone receptors on immune cells, the innervation of lymphoid organs or Tracey's inflammatory reflex theory (reviewed in [258]). However, studying the precise mechanisms of how individual neurons and neural circuits exert their effect on the immune system is challenging due to the complexity of the human nervous system, which is why C. elegans has been applied as a simple and useful model. With the well-characterized and defined number of neurons, this organism will enable the dissection of neural-immune signalling at a single cell level in the future [253].

Author Contributions: Conceptualization: S.L., Z.F., Z.B. and K.T.-V., writing-review and editing: S.L., Z.F., É.S., Z.B. and K.T.-V. All authors have read and agreed to the published version of the manuscript.

Funding: This work was supported by the National Research Fund (National Research, Development and Innovation Office) K134285 to K.T.-V., by the Eötvös Loránd Research Network (ELKH), and the ELTE Institutional Excellence Program (1783-3/2018/FEKUSTRAT; Hungarian Ministry of Human Capacities).

Institutional Review Board Statement: Not applicable.

Informed Consent Statement: Not applicable.

Conflicts of Interest: The authors declare no conflict of interest.

\section{References}

1. Gordon, S. Phagocytosis: An Immunobiologic Process. Immunity 2016, 44, 463-475. [CrossRef] [PubMed]

2. Buchmann, K. Evolution of Innate Immunity: Clues from Invertebrates via Fish to Mammals. Front. Immunol. 2014,5 , 459. [CrossRef]

3. Kim, D.H. Signaling in the Innate Immune Response; Wormbook: Pasadena, CA, USA, 2018; pp. 1-35. [CrossRef]

4. Cummings, R.J.; Barbet, G.; Bongers, G.; Hartmann, B.M.; Gettler, K.; Muniz, L.; Furtado, G.C.; Cho, J.; Lira, S.A.; Blander, J.M. Different tissue phagocytes sample apoptotic cells to direct distinct homeostasis programs. Nature 2016, 539, 565-569. [CrossRef]

5. Hart, S.P.; Dransfield, I.; Rossi, A.G. Phagocytosis of apoptotic cells. Methods 2008, 44, 280-285. [CrossRef] 
6. Cao, X. Self-regulation and cross-regulation of pattern-recognition receptor signalling in health and disease. Nat. Rev. Immunol. 2016, 16, 35-50. [CrossRef]

7. Nathan, C.; Cunningham-Bussel, A. Beyond oxidative stress: An immunologist's guide to reactive oxygen species. Nat. Rev. Immunol. 2013, 13, 349-361. [CrossRef]

8. Segal, B.H.; Grimm, M.J.; Khan, A.N.H.; Han, W.; Blackwell, T.S. Regulation of innate immunity by NADPH oxidase. Free Radic. Biol. Med. 2012, 53, 72-80. [CrossRef] [PubMed]

9. Steinbrenner, H.; Sies, H. Protection against reactive oxygen species by selenoproteins. Biochim. Biophys. Acta 2009, 1790, 1478-1485. [CrossRef]

10. Cadet, J.; Ravanat, J.-L.; TavernaPorro, M.; Menoni, H.; Angelov, D. Oxidatively generated complex DNA damage: Tandem and clustered lesions. Cancer Lett. 2012, 327, 5-15. [CrossRef]

11. Valko, M.; Leibfritz, D.; Moncol, J.; Cronin, M.T.D.; Mazur, M.; Telser, J. Free radicals and antioxidants in normal physiological functions and human disease. Int. J. Biochem. Cell Biol. 2007, 39, 44-84. [CrossRef]

12. Pacher, P.; Beckman, J.S.; Liaudet, L. Nitric oxide and peroxynitrite in health and disease. Physiol. Rev. 2007, 87, 315-424. [CrossRef]

13. Lugrin, J.; Rosenblatt-Velin, N.; Parapanov, R.; Liaudet, L. The role of oxidative stress during inflammatory processes. Biol. Chem. 2014, 395, 203-230. [CrossRef]

14. Gray, M.; Botelho, R.J. Phagocytosis: Hungry, Hungry Cells. Methods Mol. Biol. 2017, 1519, 1-16. [CrossRef] [PubMed]

15. Conradt, B.; Xue, D. Programmed Cell Death; WormBook: Pasadena, CA, USA, 2005; pp. 1-13. [CrossRef]

16. Conradt, B.; Wu, Y.-C.; Xue, D. Programmed Cell Death During Caenorhabditis elegans Development. Genetics 2016, $203,1533-1562$. [CrossRef] [PubMed]

17. Klöditz, K.; Chen, Y.Z.; Xue, D.; Fadeel, B. Programmed cell clearance: From nematodes to humans. Biochem. Biophys. Res. Commun. 2017, 482, 491-497. [CrossRef] [PubMed]

18. Wan, J.; Yuan, L.; Jing, H.; Zheng, Q.; Xiao, H. Defective apoptotic cell clearance activates innate immune response to protect Caenorhabditis elegans against pathogenic bacteria. Virulence 2021, 12, 75-83. [CrossRef] [PubMed]

19. Walpole, G.F.W.; Grinstein, S. Endocytosis and the internalization of pathogenic organisms: Focus on phosphoinositides. F1000Research 2020, 9, 1-17. [CrossRef]

20. Lim, J.P.; Gleeson, P.A. Macropinocytosis: An endocytic pathway for internalising large gulps. Immunol. Cell Biol. 2011, 89, 836-843. [CrossRef] [PubMed]

21. Canton, J.; Schlam, D.; Breuer, C.; Gütschow, M.; Glogauer, M.; Grinstein, S. Calcium-sensing receptors signal constitutive macropinocytosis and facilitate the uptake of NOD2 ligands in macrophages. Nat. Commun. 2016, 7, 11284. [CrossRef]

22. Kaksonen, M.; Roux, A. Mechanisms of clathrin-mediated endocytosis. Nat. Rev. Mol. Cell Biol. 2018, 19, 313-326. [CrossRef] [PubMed]

23. Schmid, S.L.; Frolov, V.A. Dynamin: Functional design of a membrane fission catalyst. Annu. Rev. Cell Dev. Biol. 2011, 27, 79-105. [CrossRef] [PubMed]

24. Marks, B.; Stowell, M.H.; Vallis, Y.; Mills, I.G.; Gibson, A.; Hopkins, C.R.; McMahon, H.T. GTPase activity of dynamin and resulting conformation change are essential for endocytosis. Nature 2001, 410, 231-235. [CrossRef] [PubMed]

25. Mayor, S.; Parton, R.G.; Donaldson, J.G. Clathrin-independent pathways of endocytosis. Cold Spring Harb. Perspect. Biol. 2014, 6. [CrossRef]

26. Mayor, S.; Riezman, H. Sorting GPI-anchored proteins. Nat. Rev. Mol. Cell Biol. 2004, 5, 110-120. [CrossRef]

27. Howes, M.T.; Mayor, S.; Parton, R.G. Molecules, mechanisms, and cellular roles of clathrin-independent endocytosis. Curr. Opin. Cell Biol. 2010, 22, 519-527. [CrossRef] [PubMed]

28. Kumar, V. Phagocytosis: Phenotypically Simple Yet a Mechanistically Complex Process. Int. Rev. Immunol. 2020, 39, 118-150. [CrossRef] [PubMed]

29. Mellman, I. Endocytosis and molecular sorting. Annu. Rev. Cell Dev. Biol. 1996, 12, 575-625. [CrossRef]

30. Blander, J.M.; Medzhitov, R. On regulation of phagosome maturation and antigen presentation. Nat. Immunol. 2006, 7, 1029-1035. [CrossRef] [PubMed]

31. Gruenberg, J.; van der Goot, F.G. Mechanisms of pathogen entry through the endosomal compartments. Nat. Rev. Mol. Cell Biol. 2006, 7, 495-504. [CrossRef]

32. Stenmark, H. Rab GTPases as coordinators of vesicle traffic. Nat. Rev. Mol. Cell Biol. 2009, 10, 513-525. [CrossRef] [PubMed]

33. Christoforidis, S.; McBride, H.M.; Burgoyne, R.D.; Zerial, M. The Rab5 effector EEA1 is a core component of endosome docking. Nature 1999, 397, 621-625. [CrossRef]

34. Callaghan, J.; Nixon, S.; Bucci, C.; Toh, B.H.; Stenmark, H. Direct interaction of EEA1 with Rab5b. Eur. J. Biochem. 1999, $265,361-366$. [CrossRef] [PubMed]

35. Daro, E.; van der Sluijs, P.; Galli, T.; Mellman, I. Rab4 and cellubrevin define different early endosome populations on the pathway of transferrin receptor recycling. Proc. Natl. Acad. Sci. USA 1996, 93, 9559-9564. [CrossRef]

36. van der Sluijs, P.; Hull, M.; Webster, P.; Mâle, P.; Goud, B.; Mellman, I. The small GTP-binding protein rab4 controls an early sorting event on the endocytic pathway. Cell 1992, 70, 729-740. [CrossRef] 
37. Perrin, L.; Laura, P.; Lacas-Gervais, S.; Sandra, L.-G.; Gilleron, J.; Jérôme, G.; Ceppo, F.; Franck, C.; Prodon, F.; François, P.; et al. Rab4b controls an early endosome sorting event by interacting with the $\gamma$-subunit of the clathrin adaptor complex 1 . J. Cell Sci. 2013, 126, 4950-4962. [CrossRef]

38. Rink, J.; Ghigo, E.; Kalaidzidis, Y.; Zerial, M. Rab conversion as a mechanism of progression from early to late endosomes. Cell 2005, 122, 735-749. [CrossRef]

39. Vieira, O.V.; Bucci, C.; Harrison, R.E.; Trimble, W.S.; Lanzetti, L.; Gruenberg, J.; Schreiber, A.D.; Stahl, P.D.; Grinstein, S. Modulation of Rab5 and Rab7 recruitment to phagosomes by phosphatidylinositol 3-kinase. Mol. Cell. Biol. 2003, 23, 2501-2514. [CrossRef]

40. Beyenbach, K.W.; Wieczorek, H. The V-type H+ ATPase: Molecular structure and function, physiological roles and regulation. J. Exp. Biol. 2006, 209, 577-589. [CrossRef]

41. Piper, R.C.; Katzmann, D.J. Biogenesis and function of multivesicular bodies. Annu. Rev. Cell Dev. Biol. 2007, $23,519-547$. [CrossRef]

42. Gurung, S.; Perocheau, D.; Touramanidou, L.; Baruteau, J. The exosome journey: From biogenesis to uptake and intracellular signalling. Cell Commun. Signal. 2021, 19, 1-19. [CrossRef]

43. Harding, C.V.; Geuze, H.J. Class II MHC molecules are present in macrophage lysosomes and phagolysosomes that function in the phagocytic processing of Listeria monocytogenes for presentation to T cells. J. Cell Biol. 1992, 119, 531-542. [CrossRef] [PubMed]

44. Minakami, R.; Sumimotoa, H. Phagocytosis-coupled activation of the superoxide-producing phagocyte oxidase, a member of the NADPH oxidase (nox) family. Int. J. Hematol. 2006, 84, 193-198. [CrossRef] [PubMed]

45. Balce, D.R.; Li, B.; Allan, E.R.O.; Rybicka, J.M.; Krohn, R.M.; Yates, R.M. Alternative activation of macrophages by IL-4 enhances the proteolytic capacity of their phagosomes through synergistic mechanisms. Blood 2011, 118, 4199-4208. [CrossRef] [PubMed]

46. Yates, R.M.; Hermetter, A.; Taylor, G.A.; Russell, D.G. Macrophage activation downregulates the degradative capacity of the phagosome. Traffic 2007, 8, 241-250. [CrossRef] [PubMed]

47. Gordon, S. Alternative activation of macrophages. Nat. Rev. Immunol. 2003, 3, 23-35. [CrossRef] [PubMed]

48. Delamarre, L.; Pack, M.; Chang, H.; Mellman, I.; Trombetta, E.S. Differential lysosomal proteolysis in antigen-presenting cells determines antigen fate. Science 2005, 307, 1630-1634. [CrossRef]

49. Delamarre, L.; Couture, R.; Mellman, I.; Trombetta, E.S. Enhancing immunogenicity by limiting susceptibility to lysosomal proteolysis. J. Exp. Med. 2006, 203, 2049-2055. [CrossRef]

50. Grant, B.D.; Donaldson, J.G. Pathways and mechanisms of endocytic recycling. Nat. Rev. Mol. Cell Biol. 2009, 10, 597-608. [CrossRef]

51. Lobert, V.H.; Brech, A.; Pedersen, N.M.; Wesche, J.; Oppelt, A.; Malerød, L.; Stenmark, H. Ubiquitination of alpha 5 beta 1 integrin controls fibroblast migration through lysosomal degradation of fibronectin-integrin complexes. Dev. Cell 2010, 19, 148-159. [CrossRef]

52. Roberts, M.; Barry, S.; Woods, A.; van der Sluijs, P.; Norman, J. PDGF-regulated rab4-dependent recycling of alphavbeta3 integrin from early endosomes is necessary for cell adhesion and spreading. Curr. Biol. 2001, 11, 1392-1402. [CrossRef]

53. Arjonen, A.; Alanko, J.; Veltel, S.; Ivaska, J. Distinct recycling of active and inactive $\beta 1$ integrins. Traffic 2012, 13, 610-625. [CrossRef] [PubMed]

54. Ullrich, O.; Molecular, E. Rab11 Regulates Recycling through the Pericentriolar Recycling Endosome. J. Cell Biol. 1996, 135, 913-924. [CrossRef] [PubMed]

55. Powelka, A.M.; Sun, J.; Li, J.; Gao, M.; Shaw, L.M.; Sonnenberg, A.; Hsu, V.W. Stimulation-dependent recycling of integrin beta1 regulated by ARF6 and Rab11. Traffic 2004, 5, 20-36. [CrossRef] [PubMed]

56. Balasubramanian, N.; Scott, D.W.; Castle, J.D.; Casanova, J.E.; Schwartz, M.A. Arf6 and microtubules in adhesion-dependent trafficking of lipid rafts. Nat. Cell Biol. 2007, 9, 1381-1391. [CrossRef]

57. Kouranti, I.; Sachse, M.; Arouche, N.; Goud, B.; Echard, A. Rab35 regulates an endocytic recycling pathway essential for the terminal steps of cytokinesis. Curr. Biol. 2006, 16, 1719-1725. [CrossRef]

58. Fares, H.; Grant, B. Deciphering endocytosis in Caenorhabditis elegans. Traffic 2002, 3, 11-19. [CrossRef]

59. Balklava, Z.; Pant, S.; Fares, H.; Grant, B.D. Genome-wide analysis identifies a general requirement for polarity proteins in endocytic traffic. Nat. Cell Biol. 2007, 9, 1066-1073. [CrossRef] [PubMed]

60. Fares, H.; Greenwald, I. Genetic analysis of endocytosis in Caenorhabditis elegans: Coelomocyte uptake defective mutants. Genetics 2001, 159, 133-145. [CrossRef]

61. Stuart, L.M.; Ezekowitz, R.A.B. Phagocytosis: Elegant complexity. Immunity 2005, 22, 539-550. [CrossRef] [PubMed]

62. Jin, T.; Xu, X.; Hereld, D. Chemotaxis, chemokine receptors and human disease. Cytokine 2008, 44, 1-8. [CrossRef]

63. Sozzani, S.; Sallusto, F.; Luini, W.; Zhou, D.; Piemonti, L.; Allavena, P.; Van Damme, J.; Valitutti, S.; Lanzavecchia, A.; Mantovani, A. Migration of dendritic cells in response to formyl peptides, C5a, and a distinct set of chemokines. J. Immunol. 1995, 155, 3292-3295. [CrossRef] [PubMed]

64. Liu, M.; Chen, K.; Yoshimura, T.; Liu, Y.; Gong, W.; Wang, A.; Gao, J.-L.; Murphy, P.M.; Wang, J.M. Formylpeptide receptors are critical for rapid neutrophil mobilization in host defense against Listeria monocytogenes. Sci. Rep. 2012, 2, 1-7. [CrossRef]

65. Capucetti, A.; Albano, F.; Bonecchi, R. Multiple Roles for Chemokines in Neutrophil Biology. Front. Immunol. 2020, 11, 1259. [CrossRef] [PubMed] 
66. Fitzgerald, K.A.; Kagan, J.C. Toll-like Receptors and the Control of Immunity. Cell 2020, 180, 1044-1066. [CrossRef] [PubMed]

67. Platnich, J.M.; Muruve, D.A. NOD-like receptors and inflammasomes: A review of their canonical and non-canonical signaling pathways. Arch. Biochem. Biophys. 2019, 670, 4-14. [CrossRef] [PubMed]

68. Liu, Y.; Olagnier, D.; Lin, R. Host and Viral Modulation of RIG-I-Mediated Antiviral Immunity. Front. Immunol. 2016, 7, 662. [CrossRef] [PubMed]

69. Brown, G.D.; Willment, J.A.; Whitehead, L. C-type lectins in immunity and homeostasis. Nat. Rev. Immunol. 2018, 18, 374-389. [CrossRef] [PubMed]

70. Brown, G.D.; Gordon, S. Immune recognition. A new receptor for beta-glucans. Nature 2001, 413, 36-37. [CrossRef] [PubMed]

71. Taylor, P.R.; Tsoni, S.V.; Willment, J.A.; Dennehy, K.M.; Rosas, M.; Findon, H.; Haynes, K.; Steele, C.; Botto, M.; Gordon, S.; et al. Dectin-1 is required for beta-glucan recognition and control of fungal infection. Nat. Immunol. 2007, 8, 31-38. [CrossRef] [PubMed]

72. Lima-Junior, D.S.; Mineo, T.W.P.; Calich, V.L.G.; Zamboni, D.S. Dectin-1 Activation during Leishmania amazonensis Phagocytosis Prompts Syk-Dependent Reactive Oxygen Species Production to Trigger Inflammasome Assembly and Restriction of Parasite Replication. J. Immunol. 2017, 199, 2055-2068. [CrossRef] [PubMed]

73. Yadav, M.; Schorey, J.S. The beta-glucan receptor dectin-1 functions together with TLR2 to mediate macrophage activation by mycobacteria. Blood 2006, 108, 3168-3175. [CrossRef]

74. Branzk, N.; Lubojemska, A.; Hardison, S.E.; Wang, Q.; Gutierrez, M.G.; Brown, G.D.; Papayannopoulos, V. Neutrophils sense microbe size and selectively release neutrophil extracellular traps in response to large pathogens. Nat. Immunol. 2014, 15, 1017-1025. [CrossRef] [PubMed]

75. McGreal, E.P.; Rosas, M.; Brown, G.D.; Zamze, S.; Wong, S.Y.C.; Gordon, S.; Martinez-Pomares, L.; Taylor, P.R. The carbohydraterecognition domain of Dectin-2 is a C-type lectin with specificity for high mannose. Glycobiology 2006, 16, 422-430. [CrossRef]

76. Sato, K.; Yang, X.; Yudate, T.; Chung, J.-S.; Wu, J.; Luby-Phelps, K.; Kimberly, R.P.; Underhill, D.; Cruz, P.D.; Ariizumi, K. Dectin-2 is a pattern recognition receptor for fungi that couples with the $\mathrm{FC}_{\mathrm{C}}$ receptor gamma chain to induce innate immune responses. J. Biol. Chem. 2006, 281, 38854-38866. [CrossRef] [PubMed]

77. Yonekawa, A.; Saijo, S.; Hoshino, Y.; Miyake, Y.; Ishikawa, E.; Suzukawa, M.; Inoue, H.; Tanaka, M.; Yoneyama, M.; Oh-Hora, M.; et al. Dectin-2 is a direct receptor for mannose-capped lipoarabinomannan of mycobacteria. Immunity 2014, 41, 402-413. [CrossRef] [PubMed]

78. Saijo, S.; Ikeda, S.; Yamabe, K.; Kakuta, S.; Ishigame, H.; Akitsu, A.; Fujikado, N.; Kusaka, T.; Kubo, S.; Chung, S.; et al. Dectin-2 recognition of alpha-mannans and induction of Th17 cell differentiation is essential for host defense against Candida albicans. Immunity 2010, 32, 681-691. [CrossRef]

79. Ishikawa, E.; Ishikawa, T.; Morita, Y.S.; Toyonaga, K.; Yamada, H.; Takeuchi, O.; Kinoshita, T.; Akira, S.; Yoshikai, Y.; Yamasaki, S. Direct recognition of the mycobacterial glycolipid, trehalose dimycolate, by C-type lectin Mincle. J. Exp. Med. 2009, 206, $2879-2888$. [CrossRef]

80. Lu, X.; Nagata, M.; Yamasaki, S. Mincle: 20 years of a versatile sensor of insults. Int. Immunol. 2018, 30, 233-239. [CrossRef]

81. Yamasaki, S.; Matsumoto, M.; Takeuchi, O.; Matsuzawa, T.; Ishikawa, E.; Sakuma, M.; Tateno, H.; Uno, J.; Hirabayashi, J.; Mikami, Y.; et al. C-type lectin Mincle is an activating receptor for pathogenic fungus, Malassezia. Proc. Natl. Acad. Sci. USA 2009, 106, 1897-1902. [CrossRef]

82. Behler-Janbeck, F.; Takano, T.; Maus, R.; Stolper, J.; Jonigk, D.; Tort Tarrés, M.; Fuehner, T.; Prasse, A.; Welte, T.; Timmer, M.S.M.; et al. C-type Lectin Mincle Recognizes Glucosyl-diacylglycerol of Streptococcus pneumoniae and Plays a Protective Role in Pneumococcal Pneumonia. PLoS Pathog. 2016, 12, e1006038. [CrossRef]

83. Sharma, A.; Steichen, A.L.; Jondle, C.N.; Mishra, B.B.; Sharma, J. Protective role of Mincle in bacterial pneumonia by regulation of neutrophil mediated phagocytosis and extracellular trap formation. J. Infect. Dis. 2014, 209, 1837-1846. [CrossRef] [PubMed]

84. Miyake, Y.; Toyonaga, K.; Mori, D.; Kakuta, S.; Hoshino, Y.; Oyamada, A.; Yamada, H.; Ono, K.-I.; Suyama, M.; Iwakura, Y.; et al. C-type lectin MCL is an FcR $\gamma$-coupled receptor that mediates the adjuvanticity of mycobacterial cord factor. Immunity 2013, 38, 1050-1062. [CrossRef] [PubMed]

85. Wilson, G.J.; Marakalala, M.J.; Hoving, J.C.; van Laarhoven, A.; Drummond, R.A.; Kerscher, B.; Keeton, R.; van de Vosse, E.; Ottenhoff, T.H.M.; Plantinga, T.S.; et al. The C-type lectin receptor CLECSF8/CLEC4D is a key component of anti-mycobacterial immunity. Cell Host Microbe 2015, 17, 252-259. [CrossRef] [PubMed]

86. Lobato-Pascual, A.; Saether, P.C.; Fossum, S.; Dissen, E.; Daws, M.R. Mincle, the receptor for mycobacterial cord factor, forms a functional receptor complex with MCL and FceRI- $\gamma$. Eur. J. Immunol. 2013, 43, 3167-3174. [CrossRef] [PubMed]

87. van Liempt, E.; Bank, C.M.C.; Mehta, P.; Garciá-Vallejo, J.J.; Kawar, Z.S.; Geyer, R.; Alvarez, R.A.; Cummings, R.D.; Kooyk, Y.; van Die, I. Specificity of DC-SIGN for mannose- and fucose-containing glycans. FEBS Lett. 2006, 580, 6123-6131. [CrossRef]

88. Appelmelk, B.J.; van Die, I.; van Vliet, S.J.; Vandenbroucke-Grauls, C.M.J.E.; Geijtenbeek, T.B.H.; van Kooyk, Y. Cutting edge: Carbohydrate profiling identifies new pathogens that interact with dendritic cell-specific ICAM-3-grabbing nonintegrin on dendritic cells. J. Immunol. 2003, 170, 1635-1639. [CrossRef] [PubMed]

89. Tassaneetrithep, B.; Burgess, T.H.; Granelli-Piperno, A.; Trumpfheller, C.; Finke, J.; Sun, W.; Eller, M.A.; Pattanapanyasat, K.; Sarasombath, S.; Birx, D.L.; et al. DC-SIGN (CD209) mediates dengue virus infection of human dendritic cells. J. Exp. Med. 2003, 197, 823-829. [CrossRef] [PubMed]

90. Alvarez, C.P.; Lasala, F.; Carrillo, J.; Muñiz, O.; Corbí, A.L.; Delgado, R. C-type lectins DC-SIGN and L-SIGN mediate cellular entry by Ebola virus in cis and in trans. J. Virol. 2002, 76, 6841-6844. [CrossRef] [PubMed] 
91. Marzi, A.; Gramberg, T.; Simmons, G.; Möller, P.; Rennekamp, A.J.; Krumbiegel, M.; Geier, M.; Eisemann, J.; Turza, N.; Saunier, B.; et al. DC-SIGN and DC-SIGNR interact with the glycoprotein of Marburg virus and the $S$ protein of severe acute respiratory syndrome coronavirus. J. Virol. 2004, 78, 12090-12095. [CrossRef]

92. Cormier, E.G.; Durso, R.J.; Tsamis, F.; Boussemart, L.; Manix, C.; Olson, W.C.; Gardner, J.P.; Dragic, T. L-SIGN (CD209L) and DC-SIGN (CD209) mediate transinfection of liver cells by hepatitis C virus. Proc. Natl. Acad. Sci. USA 2004, 101, 14067-14072. [CrossRef]

93. Halary, F.; Amara, A.; Lortat-Jacob, H.; Messerle, M.; Delaunay, T.; Houlès, C.; Fieschi, F.; Arenzana-Seisdedos, F.; Moreau, J.F.; Déchanet-Merville, J. Human cytomegalovirus binding to DC-SIGN is required for dendritic cell infection and target cell trans-infection. Immunity 2002, 17, 653-664. [CrossRef]

94. Geijtenbeek, T.B.H.; Kwon, D.S.; Torensma, R.; van Vliet, S.J.; van Duijnhoven, G.C.; Middel, J.; Cornelissen, I.L.M.H.A.; Nottet, H.S.L.M.; KewalRamani, V.N.; Littman, D.R.; et al. DC-SIGN, a dendritic cell-specific HIV-1-binding protein that enhances trans-infection of T cells. Cell 2000, 100, 587-597. [CrossRef]

95. Trumpfheller, C.; Park, C.G.; Finke, J.; Steinman, R.M.; Granelli-Piperno, A. Cell type-dependent retention and transmission of HIV-1 by DC-SIGN. Int. Immunol. 2003, 15, 289-298. [CrossRef] [PubMed]

96. Lambert, A.A.; Gilbert, C.; Richard, M.; Beaulieu, A.D.; Tremblay, M.J. The C-type lectin surface receptor DCIR acts as a new attachment factor for HIV-1 in dendritic cells and contributes to trans- and cis-infection pathways. Blood 2008, 112, 1299-1307. [CrossRef] [PubMed]

97. Bloem, K.; Vuist, I.M.; van der Plas, A.-J.; Knippels, L.M.J.; Garssen, J.; García-Vallejo, J.J.; van Vliet, S.J.; van Kooyk, Y. Ligand binding and signaling of dendritic cell immunoreceptor (DCIR) is modulated by the glycosylation of the carbohydrate recognition domain. PLoS ONE 2013, 8, e66266. [CrossRef] [PubMed]

98. Miller, J.L.; de Wet, B.J.M.; DeWet, B.J.M.; Martinez-Pomares, L.; Radcliffe, C.M.; Dwek, R.A.; Rudd, P.M.; Gordon, S. The mannose receptor mediates dengue virus infection of macrophages. PLoS Pathog. 2008, 4, e17. [CrossRef]

99. Nguyen, D.G.; Hildreth, J.E.K. Involvement of macrophage mannose receptor in the binding and transmission of HIV by macrophages. Eur. J. Immunol. 2003, 33, 483-493. [CrossRef]

100. Taylor, M.E.; Drickamer, K. Structural requirements for high affinity binding of complex ligands by the macrophage mannose receptor. J. Biol. Chem. 1993, 268, 399-404. [CrossRef]

101. Gazi, U.; Martinez-Pomares, L. Influence of the mannose receptor in host immune responses. Immunobiology 2009, $214,554-561$. [CrossRef]

102. Schlesinger, L.S. Macrophage phagocytosis of virulent but not attenuated strains of Mycobacterium tuberculosis is mediated by mannose receptors in addition to complement receptors. J. Immunol. 1993, 150, 2920-2930.

103. Schulert, G.S.; Allen, L.-A.H. Differential infection of mononuclear phagocytes by Francisella tularensis: Role of the macrophage mannose receptor. J. Leukoc. Biol. 2006, 80, 563-571. [CrossRef] [PubMed]

104. Feinberg, H.; Taylor, M.E.; Razi, N.; McBride, R.; Knirel, Y.A.; Graham, S.A.; Drickamer, K.; Weis, W.I. Structural basis for langerin recognition of diverse pathogen and mammalian glycans through a single binding site. J. Mol. Biol. 2011, 405, 1027-1039. [CrossRef] [PubMed]

105. Tateno, H.; Ohnishi, K.; Yabe, R.; Hayatsu, N.; Sato, T.; Takeya, M.; Narimatsu, H.; Hirabayashi, J. Dual specificity of Langerin to sulfated and mannosylated glycans via a single C-type carbohydrate recognition domain. J. Biol. Chem. 2010, 285, 6390-6400 [CrossRef] [PubMed]

106. de Jong, M.A.W.P.; Vriend, L.E.M.; Theelen, B.; Taylor, M.E.; Fluitsma, D.; Boekhout, T.; Geijtenbeek, T.B.H. C-type lectin Langerin is a beta-glucan receptor on human Langerhans cells that recognizes opportunistic and pathogenic fungi. Mol. Immunol. 2010, 47, 1216-1225. [CrossRef]

107. de Witte, L.; Nabatov, A.; Pion, M.; Fluitsma, D.; de Jong, M.A.W.P.; de Gruijl, T.; Piguet, V.; van Kooyk, Y.; Geijtenbeek, T.B.H. Langerin is a natural barrier to HIV-1 transmission by Langerhans cells. Nat. Med. 2007, 13, 367-371. [CrossRef]

108. van der Vlist, M.; de Witte, L.; de Vries, R.D.; Litjens, M.; de Jong, M.A.W.P.; Fluitsma, D.; de Swart, R.L.; Geijtenbeek, T.B.H. Human Langerhans cells capture measles virus through Langerin and present viral antigens to CD4 ${ }^{+} \mathrm{T}$ cells but are incapable of cross-presentation. Eur. J. Immunol. 2011, 41, 2619-2631. [CrossRef]

109. Stambach, N.S.; Taylor, M.E. Characterization of carbohydrate recognition by langerin, a C-type lectin of Langerhans cells. Glycobiology 2003, 13, 401-410. [CrossRef] [PubMed]

110. Penberthy, K.K.; Ravichandran, K.S. Apoptotic cell recognition receptors and scavenger receptors. Immunol. Rev. 2016, 269, 44-59. [CrossRef] [PubMed]

111. PrabhuDas, M.R.; Baldwin, C.L.; Bollyky, P.L.; Bowdish, D.M.E.; Drickamer, K.; Febbraio, M.; Herz, J.; Kobzik, L.; Krieger, M.; Loike, J.; et al. A Consensus Definitive Classification of Scavenger Receptors and Their Roles in Health and Disease. J. Immunol. 2017, 198, 3775-3789. [CrossRef] [PubMed]

112. Kodama, T.; Freeman, M.; Rohrer, L.; Zabrecky, J.; Matsudaira, P.; Krieger, M. Type I macrophage scavenger receptor contains alpha-helical and collagen-like coiled coils. Nature 1990, 343, 531-535. [CrossRef]

113. Rohrer, L.; Freeman, M.; Kodama, T.; Penman, M.; Krieger, M. Coiled-coil fibrous domains mediate ligand binding by macrophage scavenger receptor type II. Nature 1990, 343, 570-572. [CrossRef]

114. Plüddemann, A.; Neyen, C.; Gordon, S. Macrophage scavenger receptors and host-derived ligands. Methods 2007, 43, 207-217. [CrossRef] [PubMed] 
115. Dunne, D.W.; Resnick, D.; Greenberg, J.; Krieger, M.; Joiner, K.A. The type I macrophage scavenger receptor binds to gram-positive bacteria and recognizes lipoteichoic acid. Proc. Natl. Acad. Sci. USA 1994, 91, 1863-1867. [CrossRef]

116. Hampton, R.Y.; Golenbock, D.T.; Penman, M.; Krieger, M.; Raetz, C.R.H. Recognition and plasma clearance of endotoxin by scavenger receptors. Nature 1991, 352, 342-344. [CrossRef] [PubMed]

117. Palecanda, A.; Paulauskis, J.; Al-Mutairi, E.; Imrich, A.; Qin, G.; Suzuki, H.; Kodama, T.; Tryggvason, K.; Koziel, H.; Kobzik, L. Role of the scavenger receptor MARCO in alveolar macrophage binding of unopsonized environmental particles. J. Exp. Med. 1999, 189, 1497-1506. [CrossRef]

118. van der Laan, L.J.; Döpp, E.A.; Haworth, R.; Pikkarainen, T.; Kangas, M.; Elomaa, O.; Dijkstra, C.D.; Gordon, S.; Tryggvason, K.; Kraal, G. Regulation and functional involvement of macrophage scavenger receptor MARCO in clearance of bacteria in vivo. J. Immunol. 1999, 162, 939-947.

119. Greenwalt, D.E.; Lipsky, R.H.; Ockenhouse, C.F.; Ikeda, H.; Tandon, N.N.; Jamieson, G.A. Membrane glycoprotein CD36: A review of its roles in adherence, signal transduction, and transfusion medicine. Blood 1992, 80, 1105-1115. [CrossRef] [PubMed]

120. Endemann, G.; Stanton, L.W.; Madden, K.S.; Bryant, C.M.; White, R.T.; Protter, A.A. CD36 is a receptor for oxidized low density lipoprotein. J. Biol. Chem. 1993, 268, 11811-11816. [CrossRef]

121. Stuart, L.M.; Deng, J.; Silver, J.M.; Takahashi, K.; Tseng, A.A.; Hennessy, E.J.; Ezekowitz, R.A.B.; Moore, K.J. Response to Staphylococcus aureus requires CD36-mediated phagocytosis triggered by the COOH-terminal cytoplasmic domain. J. Cell Biol. 2005, 170, 477-485. [CrossRef] [PubMed]

122. Baranova, I.N.; Kurlander, R.; Bocharov, A.V.; Vishnyakova, T.G.; Chen, Z.; Remaley, A.T.; Csako, G.; Patterson, A.P.; Eggerman, T.L. Role of human CD36 in bacterial recognition, phagocytosis, and pathogen-induced JNK-mediated signaling. J. Immunol. 2008, 181, 7147-7156. [CrossRef] [PubMed]

123. Savill, J.; Hogg, N.; Haslett, C. Macrophage vitronectin receptor, CD36, and thrombospondin cooperate in recognition of neutrophils undergoing programmed cell death. Chest 1991, 99, 6S-7S. [CrossRef] [PubMed]

124. Albert, M.L.; Pearce, S.F.; Francisco, L.M.; Sauter, B.; Roy, P.; Silverstein, R.L.; Bhardwaj, N. Immature dendritic cells phagocytose apoptotic cells via alphavbeta5 and CD36, and cross-present antigens to cytotoxic T lymphocytes. J. Exp. Med. 1998, 188, 1359-1368. [CrossRef] [PubMed]

125. Adachi, H.; Tsujimoto, M.; Arai, H.; Inoue, K. Expression cloning of a novel scavenger receptor from human endothelial cells. J. Biol. Chem. 1997, 272, 31217-31220. [CrossRef]

126. Patten, D.A. SCARF1: A multifaceted, yet largely understudied, scavenger receptor. Inflamm. Res. 2018, 67, 627-632. [CrossRef] [PubMed]

127. Facciponte, J.G.; Wang, X.-Y.; Subjeck, J.R. Hsp110 and Grp170, members of the Hsp70 superfamily, bind to scavenger receptor-A and scavenger receptor expressed by endothelial cells-I. Eur. J. Immunol. 2007, 37, 2268-2279. [CrossRef] [PubMed]

128. Ramirez-Ortiz, Z.G.; Pendergraft, W.F.; Prasad, A.; Byrne, M.H.; Iram, T.; Blanchette, C.J.; Luster, A.D.; Hacohen, N.; El Khoury, J.; Means, T.K. The scavenger receptor SCARF1 mediates the clearance of apoptotic cells and prevents autoimmunity. Nat. Immunol. 2013, 14, 917-926. [CrossRef] [PubMed]

129. Singh, T.D.; Park, S.-Y.; Bae, J.; Yun, Y.; Bae, Y.-C.; Park, R.-W.; Kim, I.-S. MEGF10 functions as a receptor for the uptake of amyloid- $\beta$. FEBS Lett. 2010, 584, 3936-3942. [CrossRef] [PubMed]

130. Iram, T.; Ramirez-Ortiz, Z.; Byrne, M.H.; Coleman, U.A.; Kingery, N.D.; Means, T.K.; Frenkel, D.; El Khoury, J. Megf10 Is a Receptor for C1Q That Mediates Clearance of Apoptotic Cells by Astrocytes. J. Neurosci. 2016, 36, 5185-5192. [CrossRef]

131. Park, S.-Y.; Jung, M.-Y.; Lee, S.-J.; Kang, K.-B.; Gratchev, A.; Riabov, V.; Kzhyshkowska, J.; Kim, I.-S. Stabilin-1 mediates phosphatidylserine-dependent clearance of cell corpses in alternatively activated macrophages. J. Cell Sci. 2009, 122, 3365-3373. [CrossRef] [PubMed]

132. Park, S.-Y.; Jung, M.-Y.; Kim, H.-J.; Lee, S.-J.; Kim, S.-Y.; Lee, B.-H.; Kwon, T.-H.; Park, R.-W.; Kim, I.-S. Rapid cell corpse clearance by stabilin-2, a membrane phosphatidylserine receptor. Cell Death Differ. 2008, 15, 192-201. [CrossRef] [PubMed]

133. Adachi, H.; Tsujimoto, M. FEEL-1, a novel scavenger receptor with in vitro bacteria-binding and angiogenesis-modulating activities. J. Biol. Chem. 2002, 277, 34264-34270. [CrossRef]

134. Hirose, Y.; Saijou, E.; Sugano, Y.; Takeshita, F.; Nishimura, S.; Nonaka, H.; Chen, Y.-R.; Sekine, K.; Kido, T.; Nakamura, T.; et al. Inhibition of Stabilin-2 elevates circulating hyaluronic acid levels and prevents tumor metastasis. Proc. Natl. Acad. Sci. USA 2012, 109, 4263-4268. [CrossRef]

135. Kim, S.; Park, S.-Y.; Kim, S.-Y.; Bae, D.-J.; Pyo, J.-H.; Hong, M.; Kim, I.-S. Cross talk between engulfment receptors stabilin-2 and integrin $\alpha \mathrm{v} \beta 5$ orchestrates engulfment of phosphatidylserine-exposed erythrocytes. Mol. Cell. Biol. 2012, 32, $2698-2708$. [CrossRef] [PubMed]

136. Lukácsi, S.; Mácsik-Valent, B.; Nagy-Baló, Z.; Kovács, K.G.; Kliment, K.; Bajtay, Z.; Erdei, A. Utilization of complement receptors in immune cell-Microbe interaction. FEBS Lett. 2020, 1-19. [CrossRef] [PubMed]

137. van Lookeren Campagne, M.; Wiesmann, C.; Brown, E.J. Macrophage complement receptors and pathogen clearance. Cell. Microbiol. 2007, 9, 2095-2102. [CrossRef]

138. Cornacoff, J.B.; Hebert, L.A.; Smead, W.L.; VanAman, M.E.; Birmingham, D.J.; Waxman, F.J. Primate erythrocyte-immune complex-clearing mechanism. J. Clin. Invest. 1983, 71, 236-247. [CrossRef] [PubMed]

139. Ogembo, J.G.; Kannan, L.; Ghiran, I.; Nicholson-Weller, A.; Finberg, R.W.; Tsokos, G.C.; Fingeroth, J.D. Human complement receptor type 1/CD35 is an Epstein-Barr Virus receptor. Cell Rep. 2013, 3, 371-385. [CrossRef] [PubMed] 
140. Thieblemont, N.; Haeffner-Cavaillon, N.; Ledur, A.; L'Age-Stehr, J.; Ziegler-Heitbrock, H.W.L.; Kazatchkine, M.D. CR1 (CD35) and CR3 (CD11b/CD18) mediate infection of human monocytes and monocytic cell lines with complement-opsonized HIV independently of CD4. Clin. Exp. Immunol. 1993, 92, 106-113. [CrossRef]

141. Fällman, M.; Andersson, R.; Andersson, T. Signaling properties of CR3 (CD11b/CD18) and CR1 (CD35) in relation to phagocytosis of complement-opsonized particles. J. Immunol. 1993, 151, 330-338. [PubMed]

142. He, J.Q.; Katschke, K.J.; Gribling, P.; Suto, E.; Lee, W.P.; Diehl, L.; Eastham-Anderson, J.; Ponakala, A.; Komuves, L.; Egen, J.G.; et al. CRIg mediates early Kupffer cell responses to adenovirus. J. Leukoc. Biol. 2013, 93, 301-306. [CrossRef]

143. Helmy, K.Y.; Katschke, K.J.; Gorgani, N.N.; Kljavin, N.M.; Elliott, J.M.; Diehl, L.; Scales, S.J.; Ghilardi, N.; van Lookeren Campagne, M. CRIg: A macrophage complement receptor required for phagocytosis of circulating pathogens. Cell 2006, 124, 915-927. [CrossRef]

144. Munawara, U.; Small, A.G.; Quach, A.; Gorgani, N.N.; Abbott, C.A.; Ferrante, A. Cytokines regulate complement receptor immunoglobulin expression and phagocytosis of Candida albicans in human macrophages: A control point in anti-microbial immunity. Sci. Rep. 2017, 7, 1-16. [CrossRef]

145. Erdei, A.; Lukácsi, S.; Mácsik-Valent, B.; Nagy-Baló, Z.; Kurucz, I.; Bajtay, Z. Non-identical twins: Different faces of CR3 and CR4 in myeloid and lymphoid cells of mice and men. Semin. Cell Dev. Biol. 2019, 85, 110-121. [CrossRef] [PubMed]

146. Diamond, M.S.; Garcia-Aguilar, J.; Bickford, J.K.; Corbi, A.L.; Springer, T.A. The I domain is a major recognition site on the leukocyte integrin Mac-1 (CD11b/CD18) for four distinct adhesion ligands. J. Cell Biol. 1993, 120, 1031-1043. [CrossRef] [PubMed]

147. O’Brien, X.M.; Heflin, K.E.; Lavigne, L.M.; Yu, K.; Kim, M.; Salomon, A.R.; Reichner, J.S. Lectin site ligation of CR3 induces conformational changes and signaling. J. Biol. Chem. 2012, 287, 3337-3348. [CrossRef]

148. Ross, G.D.; Cain, J.A.; Myones, B.L.; Newman, S.L.; Lachmann, P.J. Specificity of membrane complement receptor type three (CR3) for beta-glucans. Complement 1987, 4, 61-74. [CrossRef] [PubMed]

149. Wright, S.D.; Levin, S.M.; Jong, M.T.; Chad, Z.; Kabbash, L.G. CR3 (CD11b/CD18) expresses one binding site for Arg-Gly-Aspcontaining peptides and a second site for bacterial lipopolysaccharide. J. Exp. Med. 1989, 169, 175-183. [CrossRef] [PubMed]

150. Ingalls, R.R.; Golenbock, D.T. CD11c/CD18, a transmembrane signaling receptor for lipopolysaccharide. J. Exp. Med. 1995, 181, 1473-1479. [CrossRef]

151. Jawhara, S.; Pluskota, E.; Cao, W.; Plow, E.F.; Soloviev, D.A. Distinct Effects of Integrins $\alpha$ X $\beta 2$ and $\alpha M \beta 2$ on Leukocyte Subpopulations during Inflammation and Antimicrobial Responses. Infect. Immun. 2017, 85, 1-17. [CrossRef] [PubMed]

152. Hirsch, C.S.; Ellner, J.J.; Russell, D.G.; Rich, E.A. Complement receptor-mediated uptake and tumor necrosis factor-alpha-mediated growth inhibition of Mycobacterium tuberculosis by human alveolar macrophages. J. Immunol. 1994, 152, 743-753. [PubMed]

153. Sándor, N.; Kristóf, K.; Paréj, K.; Pap, D.; Erdei, A.; Bajtay, Z. CR3 is the dominant phagocytotic complement receptor on human dendritic cells. Immunobiology 2013, 218, 652-663. [CrossRef] [PubMed]

154. Lukácsi, S.; Nagy-Baló, Z.; Erdei, A.; Sándor, N.; Bajtay, Z. The role of CR3 (CD11b/CD18) and CR4 (CD11c/CD18) in complementmediated phagocytosis and podosome formation by human phagocytes. Immunol. Lett. 2017, 189, 64-72. [CrossRef]

155. Wright, S.D.; Ramos, R.A.; Tobias, P.S.; Ulevitch, R.J.; Mathison, J.C. CD14, a receptor for complexes of lipopolysaccharide (LPS) and LPS binding protein. Science 1990, 249, 1431-1433. [CrossRef]

156. van Vliet, S.J.; van Liempt, E.; Saeland, E.; Aarnoudse, C.A.; Appelmelk, B.; Irimura, T.; Geijtenbeek, T.B.H.; Blixt, O.; Alvarez, R.; van Die, I.; et al. Carbohydrate profiling reveals a distinctive role for the C-type lectin MGL in the recognition of helminth parasites and tumor antigens by dendritic cells. Int. Immunol. 2005, 17, 661-669. [CrossRef] [PubMed]

157. Sankala, M.; Brännström, A.; Schulthess, T.; Bergmann, U.; Morgunova, E.; Engel, J.; Tryggvason, K.; Pikkarainen, T. Characterization of recombinant soluble macrophage scavenger receptor MARCO. J. Biol. Chem. 2002, 277, 33378-33385. [CrossRef] [PubMed]

158. Elomaa, O.; Kangas, M.; Sahlberg, C.; Tuukkanen, J.; Sormunen, R.; Liakka, A.; Thesleff, I.; Kraal, G.; Tryggvason, K. Cloning of a novel bacteria-binding receptor structurally related to scavenger receptors and expressed in a subset of macrophages. Cell 1995, 80, 603-609. [CrossRef]

159. Harris, E.N.; Weigel, J.A.; Weigel, P.H. The human hyaluronan receptor for endocytosis (HARE/Stabilin-2) is a systemic clearance receptor for heparin. J. Biol. Chem. 2008, 283, 17341-17350. [CrossRef]

160. Sim, R.B.; Malhotra, V.; Day, A.J.; Erdei, A. Structure and specificity of complement receptors. Immunol. Lett. 1987, 14, 183-190. [CrossRef]

161. Ghiran, I.; Barbashov, S.F.; Klickstein, L.B.; Tas, S.W.; Jensenius, J.C.; Nicholson-Weller, A. Complement receptor $1 /$ CD35 is a receptor for mannan-binding lectin. J. Exp. Med. 2000, 192, 1797-1808. [CrossRef] [PubMed]

162. Losse, J.; Zipfel, P.F.; Józsi, M. Factor H and factor H-related protein 1 bind to human neutrophils via complement receptor 3 , mediate attachment to Candida albicans, and enhance neutrophil antimicrobial activity. J. Immunol. 2010, 184, 912-921. [CrossRef] [PubMed]

163. Malhotra, V.; Hogg, N.; Sim, R.B. Ligand binding by the p150,95 antigen of U937 monocytic cells: Properties in common with complement receptor type 3 (CR3). Eur. J. Immunol. 1986, 16, 1117-1123. [CrossRef] [PubMed]

164. Józsi, M.; Schneider, A.E.; Kárpáti, É.; Sándor, N. Complement factor H family proteins in their non-canonical role as modulators of cellular functions. Semin. Cell Dev. Biol. 2018, 85, 1-10. [CrossRef] [PubMed]

165. Robertson, A.M.G.; Thomson, J.N. Morphology of programmed cell death in the ventral nerve cord of Caenorhabditis elegans larvae. Development 1982, 67, 89-100. [CrossRef] 
166. Sulston, J.E.; Schierenberg, E.; White, J.G.; Thomson, J.N. The embryonic cell lineage of the nematode Caenorhabditis elegans. Dev. Biol. 1983, 100, 64-119. [CrossRef]

167. Pukkila-Worley, R. Surveillance Immunity: An Emerging Paradigm of Innate Defense Activation in Caenorhabditis elegans. PLoS Pathog. 2016, 12, e1005795. [CrossRef]

168. Huang, G.; Shi, L.Z.; Chi, H. Regulation of JNK and p38 MAPK in the immune system: Signal integration, propagation and termination. Cytokine 2009, 48, 161-169. [CrossRef]

169. Keshet, Y.; Seger, R. The MAP kinase signaling cascades: A system of hundreds of components regulates a diverse array of physiological functions. Methods Mol. Biol. 2010, 661, 3-38. [CrossRef]

170. Kim, D.H.; Feinbaum, R.; Alloing, G.; Emerson, F.E.; Garsin, D.A.; Inoue, H.; Tanaka-Hino, M.; Hisamoto, N.; Matsumoto, K.; Tan, M.-W.; et al. A conserved p38 MAP kinase pathway in Caenorhabditis elegans innate immunity. Science 2002, 297, 623-626. [CrossRef]

171. Kim, D.H.; Liberati, N.T.; Mizuno, T.; Inoue, H.; Hisamoto, N.; Matsumoto, K.; Ausubel, F.M. Integration of Caenorhabditis elegans MAPK pathways mediating immunity and stress resistance by MEK-1 MAPK kinase and VHP-1 MAPK phosphatase. Proc. Natl. Acad. Sci. USA 2004, 101, 10990-10994. [CrossRef] [PubMed]

172. Aballay, A.; Drenkard, E.; Hilbun, L.R.; Ausubel, F.M. Caenorhabditis elegans innate immune response triggered by Salmonella enterica requires intact LPS and is mediated by a MAPK signaling pathway. Curr. Biol. 2003, 13, 47-52. [CrossRef]

173. Sifri, C.D.; Begun, J.; Ausubel, F.M.; Calderwood, S.B. Caenorhabditis elegans as a model host for Staphylococcus aureus pathogenesis Infect. Immun. 2003, 71, 2208-2217. [CrossRef]

174. Bolz, D.D.; Tenor, J.L.; Aballay, A. A conserved PMK-1/p38 MAPK is required in caenorhabditis elegans tissue-specific immune response to Yersinia pestis infection. J. Biol. Chem. 2010, 285, 10832-10840. [CrossRef] [PubMed]

175. Pukkila-Worley, R.; Ausubel, F.M.; Mylonakis, E. Candida albicans infection of Caenorhabditis elegans induces antifungal immune defenses. PLoS Pathog. 2011, 7, e1002074. [CrossRef]

176. Muhammed, M.; Fuchs, B.B.; Wu, M.P.; Breger, J.; Coleman, J.J.; Mylonakis, E. The role of mycelium production and a MAPKmediated immune response in the C. elegans-Fusarium model system. Med. Mycol. 2012, 50, 488-496. [CrossRef] [PubMed]

177. Huffman, D.L.; Abrami, L.; Sasik, R.; Corbeil, J.; van der Goot, F.G.; Aroian, R.V. Mitogen-activated protein kinase pathways defend against bacterial pore-forming toxins. Proc. Natl. Acad. Sci. USA 2004, 101, 10995-11000. [CrossRef]

178. Hodgkin, J.; Kuwabara, P.E.; Corneliussen, B. A novel bacterial pathogen, Microbacterium nematophilum, induces morphological change in the nematode C. elegans. Curr. Biol. 2000, 10, 1615-1618. [CrossRef]

179. Kurz, C.L.; Ewbank, J.J. Caenorhabditis elegans: An emerging genetic model for the study of innate immunity. Nat. Rev. Genet. 2003, 4, 380-390. [CrossRef]

180. Nicholas, H.R.; Hodgkin, J. Responses to infection and possible recognition strategies in the innate immune system of Caenorhabditis elegans. Mol. Immunol. 2004, 41, 479-493. [CrossRef]

181. Couillault, C.; Pujol, N.; Reboul, J.; Sabatier, L.; Guichou, J.-F.; Kohara, Y.; Ewbank, J.J. TLR-independent control of innate immunity in Caenorhabditis elegans by the TIR domain adaptor protein TIR-1, an ortholog of human SARM. Nat. Immunol. 2004, 5, 488-494. [CrossRef]

182. Irazoqui, J.E.; Urbach, J.M.; Ausubel, F.M. Evolution of host innate defence: Insights from Caenorhabditis elegans and primitive invertebrates. Nat. Rev. Immunol. 2010, 10, 47-58. [CrossRef]

183. Brandt, J.P.; Ringstad, N. Toll-like Receptor Signaling Promotes Development and Function of Sensory Neurons Required for a C. elegans Pathogen-Avoidance Behavior. Curr. Biol. 2015, 25, 2228-2237. [CrossRef] [PubMed]

184. Pujol, N.; Link, E.M.; Liu, L.X.; Kurz, C.L.; Alloing, G.; Tan, M.W.; Ray, K.P.; Solari, R.; Johnson, C.D.; Ewbank, J.J. A reverse genetic analysis of components of the Toll signaling pathway in Caenorhabditis elegans. Curr. Biol. 2001, 11, 809-821. [CrossRef]

185. Liberati, N.T.; Fitzgerald, K.A.; Kim, D.H.; Feinbaum, R.; Golenbock, D.T.; Ausubel, F.M. Requirement for a conserved Toll/interleukin-1 resistance domain protein in the Caenorhabditis elegans immune response. Proc. Natl. Acad. Sci. USA 2004, 101, 6593-6598. [CrossRef] [PubMed]

186. Matzinger, P. The danger model: A renewed sense of self. Science 2002, 296, 301-305. [CrossRef] [PubMed]

187. Seong, S.-Y.; Matzinger, P. Hydrophobicity: An ancient damage-associated molecular pattern that initiates innate immune responses. Nat. Rev. Immunol. 2004, 4, 469-478. [CrossRef]

188. Pujol, N.; Cypowyj, S.; Ziegler, K.; Millet, A.; Astrain, A.; Goncharov, A.; Jin, Y.; Chisholm, A.D.; Ewbank, J.J. Distinct innate immune responses to infection and wounding in the C. elegans epidermis. Curr. Biol. 2008, 18, 481-489. [CrossRef]

189. Bischof, L.J.; Kao, C.-Y.; Los, F.C.O.; Gonzalez, M.R.; Shen, Z.; Briggs, S.P.; van der Goot, F.G.; Aroian, R.V. Activation of the unfolded protein response is required for defenses against bacterial pore-forming toxin in vivo. PLoS Pathog. 2008, 4, e1000176. [CrossRef] [PubMed]

190. Zugasti, O.; Bose, N.; Squiban, B.; Belougne, J.; Kurz, C.L.; Schroeder, F.C.; Pujol, N.; Ewbank, J.J. Activation of a G protein-coupled receptor by its endogenous ligand triggers the innate immune response of Caenorhabditis elegans. Nat. Immunol. 2014, 15, 833-838. [CrossRef] [PubMed]

191. Ziegler, K.; Kurz, C.L.; Cypowyj, S.; Couillault, C.; Pophillat, M.; Pujol, N.; Ewbank, J.J. Antifungal innate immunity in C. elegans: PKCdelta links G protein signaling and a conserved p38 MAPK cascade. Cell Host Microbe 2009, 5, 341-352. [CrossRef] 
192. Dierking, K.; Polanowska, J.; Omi, S.; Engelmann, I.; Gut, M.; Lembo, F.; Ewbank, J.J.; Pujol, N. Unusual regulation of a STAT protein by an SLC6 family transporter in C. elegans epidermal innate immunity. Cell Host Microbe 2011, 9, 425-435. [CrossRef] [PubMed]

193. Pujol, N.; Zugasti, O.; Wong, D.; Couillault, C.; Kurz, C.L.; Schulenburg, H.; Ewbank, J.J. Anti-fungal innate immunity in C. elegans is enhanced by evolutionary diversification of antimicrobial peptides. PLoS Pathog. 2008, 4, e1000105. [CrossRef] [PubMed]

194. Quintana, J.A.; García-Silva, S.; Mazariegos, M.; González de la Aleja, A.; Nicolás-Ávila, J.A.; Walter, W.; Adrover, J.M.; Crainiciuc, G.; Kuchroo, V.K.; Rothlin, C.V.; et al. Phagocytosis imprints heterogeneity in tissue-resident macrophages. J. Exp. Med. 2017, 214, 1281-1296. [CrossRef]

195. Roberts, A.W.; Lee, B.L.; Deguine, J.; John, S.; Shlomchik, M.J.; Barton, G.M. Tissue-Resident Macrophages Are Locally Programmed for Silent Clearance of Apoptotic Cells. Immunity 2017, 47, 913-927.e6. [CrossRef] [PubMed]

196. Fadok, V.A.; Voelker, D.R.; Campbell, P.A.; Cohen, J.J.; Bratton, D.L.; Henson, P.M. Exposure of phosphatidylserine on the surface of apoptotic lymphocytes triggers specific recognition and removal by macrophages. J. Immunol. 1992, 148, 2207-2216. [CrossRef] [PubMed]

197. Andersen, J.P.; Vestergaard, A.L.; Mikkelsen, S.A.; Mogensen, L.S.; Chalat, M.; Molday, R.S. P4-ATPases as Phospholipid Flippases-Structure, Function, and Enigmas. Front. Physiol. 2016, 7, 275. [CrossRef] [PubMed]

198. Segawa, K.; Kurata, S.; Yanagihashi, Y.; Brummelkamp, T.R.; Matsuda, F.; Nagata, S. Caspase-mediated cleavage of phospholipid flippase for apoptotic phosphatidylserine exposure. Science 2014, 344, 1164-1168. [CrossRef] [PubMed]

199. Suzuki, J.; Denning, D.P.; Imanishi, E.; Horvitz, H.R.; Nagata, S. Xk-related protein 8 and CED-8 promote phosphatidylserine exposure in apoptotic cells. Science 2013, 341, 403-406. [CrossRef]

200. Fadok, V.A.; Bratton, D.L.; Rose, D.M.; Pearson, A.; Ezekewitz, R.A.; Henson, P.M. A receptor for phosphatidylserine-specific clearance of apoptotic cells. Nature 2000, 405, 85-90. [CrossRef]

201. Williamson, P.; Schlegel, R.A. Hide and seek: The secret identity of the phosphatidylserine receptor. J. Biol. 2004, 3, 1-4. [CrossRef] [PubMed]

202. Klose, R.J.; Kallin, E.M.; Zhang, Y. JmjC-domain-containing proteins and histone demethylation. Nat. Rev. Genet. 2006, 7, 715-727. [CrossRef] [PubMed]

203. Böse, J.; Gruber, A.D.; Helming, L.; Schiebe, S.; Wegener, I.; Hafner, M.; Beales, M.; Köntgen, F.; Lengeling, A. The phosphatidylserine receptor has essential functions during embryogenesis but not in apoptotic cell removal. J. Biol. 2004, 3, 715-727. [CrossRef] [PubMed]

204. Umetsu, S.E.; Lee, W.-L.; McIntire, J.J.; Downey, L.; Sanjanwala, B.; Akbari, O.; Berry, G.J.; Nagumo, H.; Freeman, G.J.; Umetsu, D.T.; et al. TIM-1 induces T cell activation and inhibits the development of peripheral tolerance. Nat. Immunol. 2005, 6, 447-454. [CrossRef]

205. Ichimura, T.; Asseldonk, E.J.P.V.; Humphreys, B.D.; Gunaratnam, L.; Duffield, J.S.; Bonventre, J.V. Kidney injury molecule-1 is a phosphatidylserine receptor that confers a phagocytic phenotype on epithelial cells. J. Clin. Invest. 2008, 118, 1657-1668 [CrossRef]

206. Monney, L.; Sabatos, C.A.; Gaglia, J.L.; Ryu, A.; Waldner, H.; Chernova, T.; Manning, S.; Greenfield, E.A.; Coyle, A.J.; Sobel, R.A.; et al. Th1-specific cell surface protein Tim-3 regulates macrophage activation and severity of an autoimmune disease. Nature 2002, 415, 536-541. [CrossRef] [PubMed]

207. Anderson, A.C.; Anderson, D.E.; Bregoli, L.; Hastings, W.D.; Kassam, N.; Lei, C.; Chandwaskar, R.; Karman, J.; Su, E.W.; Hirashima, M.; et al. Promotion of tissue inflammation by the immune receptor Tim-3 expressed on innate immune cells. Science 2007, 318, 1141-1143. [CrossRef] [PubMed]

208. de Mingo Pulido, Á.; Gardner, A.; Hiebler, S.; Soliman, H.; Rugo, H.S.; Krummel, M.F.; Coussens, L.M.; Ruffell, B. TIM-3 Regulates CD103+ Dendritic Cell Function and Response to Chemotherapy in Breast Cancer. Cancer Cell 2018, 33, 60-74.e6. [CrossRef] [PubMed]

209. Kobayashi, N.; Karisola, P.; Peña-Cruz, V.; Dorfman, D.M.; Jinushi, M.; Umetsu, S.E.; Butte, M.J.; Nagumo, H.; Chernova, I.; Zhu, B.; et al. TIM-1 and TIM-4 glycoproteins bind phosphatidylserine and mediate uptake of apoptotic cells. Immunity 2007, 27, 927-940. [CrossRef] [PubMed]

210. Miyanishi, M.; Tada, K.; Koike, M.; Uchiyama, Y.; Kitamura, T.; Nagata, S. Identification of Tim4 as a phosphatidylserine receptor. Nature 2007, 450, 435-439. [CrossRef] [PubMed]

211. Lemke, G. How macrophages deal with death. Nat. Rev. Immunol. 2019, 19, 539-549. [CrossRef] [PubMed]

212. Nagata, S. Apoptosis and Clearance of Apoptotic Cells. Annu. Rev. Immunol. 2018, 36, 489-517. [CrossRef] [PubMed]

213. Lew, E.D.; Oh, J.; Burrola, P.G.; Lax, I.; Zagórska, A.; Través, P.G.; Schlessinger, J.; Lemke, G. Differential TAM receptor-ligandphospholipid interactions delimit differential TAM bioactivities. Elife 2014, 3, 1-23. [CrossRef]

214. Seitz, H.M.; Camenisch, T.D.; Lemke, G.; Earp, H.S.; Matsushima, G.K. Macrophages and dendritic cells use different Axl/Mertk/Tyro3 receptors in clearance of apoptotic cells. J. Immunol. 2007, 178, 5635-5642. [CrossRef] [PubMed]

215. Rothlin, C.V.; Ghosh, S.; Zuniga, E.I.; Oldstone, M.B.A.; Lemke, G. TAM receptors are pleiotropic inhibitors of the innate immune response. Cell 2007, 131, 1124-1136. [CrossRef] [PubMed]

216. van der Meer, J.H.M.; van der Poll, T.; van 't Veer, C. TAM receptors, Gas6, and protein S: Roles in inflammation and hemostasis. Blood 2014, 123, 2460-2469. [CrossRef] 
217. Hanayama, R.; Tanaka, M.; Miwa, K.; Shinohara, A.; Iwamatsu, A.; Nagata, S. Identification of a factor that links apoptotic cells to phagocytes. Nature 2002, 417, 182-187. [CrossRef]

218. Stern, M.; Savill, J.; Haslett, C. Human monocyte-derived macrophage phagocytosis of senescent eosinophils undergoing apoptosis. Mediation by alpha $\mathrm{v}$ beta 3/CD36/thrombospondin recognition mechanism and lack of phlogistic response. Am. J. Pathol. 1996, 149, 911-921.

219. Savill, J.; Hogg, N.; Ren, Y.; Haslett, C. Thrombospondin cooperates with CD36 and the vitronectin receptor in macrophage recognition of neutrophils undergoing apoptosis. J. Clin. Invest. 1992, 90, 1513-1522. [CrossRef]

220. Albert, M.L.; Kim, J.I.; Birge, R.B. alphavbeta5 integrin recruits the CrkII-Dock180-rac1 complex for phagocytosis of apoptotic cells. Nat. Cell Biol. 2000, 2, 899-905. [CrossRef]

221. Gumienny, T.L.; Brugnera, E.; Tosello-Trampont, A.C.; Kinchen, J.M.; Haney, L.B.; Nishiwaki, K.; Walk, S.F.; Nemergut, M.E.; Macara, I.G.; Francis, R.; et al. CED-12/ELMO, a novel member of the CrkII/Dock180/Rac pathway, is required for phagocytosis and cell migration. Cell 2001, 107, 27-41. [CrossRef]

222. Shah, P.P.; Fong, M.Y.; Kakar, S.S. PTTG induces EMT through integrin $\alpha \mathrm{V} \beta 3$-focal adhesion kinase signaling in lung cancer cells. Oncogene 2012, 31, 3124-3135. [CrossRef]

223. Liang, Y.Y.; Arnold, T.; Michlmayr, A.; Rainprecht, D.; Perticevic, B.; Spittler, A.; Oehler, R. Serum-dependent processing of late apoptotic cells for enhanced efferocytosis. Cell Death Dis. 2014, 5, e1264. [CrossRef]

224. Nauta, A.J.; Castellano, G.; Xu, W.; Woltman, A.M.; Borrias, M.C.; Daha, M.R.; van Kooten, C.; Roos, A. Opsonization with C1q and mannose-binding lectin targets apoptotic cells to dendritic cells. J. Immunol. 2004, 173, 3044-3050. [CrossRef] [PubMed]

225. Fraser, D.A.; Laust, A.K.; Nelson, E.L.; Tenner, A.J. C1q differentially modulates phagocytosis and cytokine responses during ingestion of apoptotic cells by human monocytes, macrophages, and dendritic cells. J. Immunol. 2009, 183, 6175-6185. [CrossRef]

226. Takizawa, F.; Tsuji, S.; Nagasawa, S. Enhancement of macrophage phagocytosis upon iC3b deposition on apoptotic cells. FEBS Lett. 1996, 397, 269-272. [CrossRef]

227. Matsui, H.; Tsuji, S.; Nishimura, H.; Nagasawa, S. Activation of the alternative pathway of complement by apoptotic Jurkat cells. FEBS Lett. 1994, 351, 419-422. [CrossRef]

228. Mevorach, D.; Mascarenhas, J.O.; Gershov, D.; Elkon, K.B. Complement-dependent clearance of apoptotic cells by human macrophages. J. Exp. Med. 1998, 188, 2313-2320. [CrossRef]

229. Benoit, M.E.; Clarke, E.V.; Morgado, P.; Fraser, D.A.; Tenner, A.J. Complement protein C1q directs macrophage polarization and limits inflammasome activity during the uptake of apoptotic cells. J. Immunol. 2012, 188, 5682-5693. [CrossRef]

230. Fraser, D.A.; Arora, M.; Bohlson, S.S.; Lozano, E.; Tenner, A.J. Generation of inhibitory NFkappaB complexes and phosphorylated cAMP response element-binding protein correlates with the anti-inflammatory activity of complement protein C1q in human monocytes. J. Biol. Chem. 2007, 282, 7360-7367. [CrossRef] [PubMed]

231. Bratton, D.L.; Fadok, V.A.; Richter, D.A.; Kailey, J.M.; Guthrie, L.A.; Henson, P.M. Appearance of phosphatidylserine on apoptotic cells requires calcium-mediated nonspecific flip-flop and is enhanced by loss of the aminophospholipid translocase. J. Biol. Chem. 1997, 272, 26159-26165. [CrossRef]

232. Lu, N.; Zhou, Z. Membrane trafficking and phagosome maturation during the clearance of apoptotic cells. Int. Rev. Cell Mol. Biol. 2012, 293, 269-309. [CrossRef] [PubMed]

233. Mangahas, P.M.; Zhou, Z. Clearance of apoptotic cells in Caenorhabditis elegans. Semin. Cell Dev. Biol. 2005, 16, 295-306. [CrossRef] [PubMed]

234. Kinchen, J.M.; Cabello, J.; Klingele, D.; Wong, K.; Feichtinger, R.; Schnabel, H.; Schnabel, R.; Hengartner, M.O. Two pathways converge at CED-10 to mediate actin rearrangement and corpse removal in C. elegans. Nature 2005, 434, 93-99. [CrossRef] [PubMed]

235. Shen, Q.; He, B.; Lu, N.; Conradt, B.; Grant, B.D.; Zhou, Z. Phagocytic receptor signaling regulates clathrin and epsin-mediated cytoskeletal remodeling during apoptotic cell engulfment in C. elegans. Development 2013, 140, 3230-3243. [CrossRef]

236. Zhou, Z.; Hartwieg, E.; Horvitz, H.R. CED-1 is a transmembrane receptor that mediates cell corpse engulfment in C. elegans. Cell 2001, 104, 43-56. [CrossRef]

237. Venegas, V.; Zhou, Z. Two alternative mechanisms that regulate the presentation of apoptotic cell engulfment signal in Caenorhabditis elegans. Mol. Biol. Cell 2007, 18, 3180-3192. [CrossRef]

238. Yu, X.; Odera, S.; Chuang, C.-H.; Lu, N.; Zhou, Z. C. elegans Dynamin mediates the signaling of phagocytic receptor CED-1 for the engulfment and degradation of apoptotic cells. Dev. Cell 2006, 10, 743-757. [CrossRef] [PubMed]

239. Farkas, Z.; Petric, M.; Liu, X.; Herit, F.; Rajnavölgyi, É.; Szondy, Z.; Budai, Z.; Orbán, T.I.; Sándor, S.; Mehta, A.; et al. The nucleoside diphosphate kinase NDK-1/NME1 promotes phagocytosis in concert with DYN-1/Dynamin. FASEB J. 2019, 33, 11606-11614. [CrossRef]

240. Yu, X.; Lu, N.; Zhou, Z. Phagocytic receptor CED-1 initiates a signaling pathway for degrading engulfed apoptotic cells. PLoS Biol. 2008, 6, e61. [CrossRef]

241. Reddien, P.W.; Horvitz, H.R. The engulfment process of programmed cell death in Caenorhabditis elegans. Annu. Rev. Cell Dev. Biol. 2004, 20, 193-221. [CrossRef] [PubMed]

242. Hsu, T.-Y.; Wu, Y.-C. Engulfment of apoptotic cells in C. elegans is mediated by integrin alpha/SRC signaling. Curr. Biol. 2010, 20, 477-486. [CrossRef] 
243. Wang, X.; Wu, Y.-C.; Fadok, V.A.; Lee, M.-C.; Gengyo-Ando, K.; Cheng, L.-C.; Ledwich, D.; Hsu, P.-K.; Chen, J.-Y.; Chou, B.-K.; et al. Cell corpse engulfment mediated by C. elegans phosphatidylserine receptor through CED-5 and CED-12. Science 2003, 302, 1563-1566. [CrossRef] [PubMed]

244. Hsieh, H.-H.; Hsu, T.-Y.; Jiang, H.-S.; Wu, Y.-C. Integrin $\alpha$ PAT-2/CDC-42 signaling is required for muscle-mediated clearance of apoptotic cells in Caenorhabditis elegans. PLoS Genet. 2012, 8, e1002663. [CrossRef]

245. Neukomm, L.J.; Zeng, S.; Frei, A.P.; Huegli, P.A.; Hengartner, M.O. Small GTPase CDC-42 promotes apoptotic cell corpse clearance in response to PAT-2 and CED-1 in C. elegans. Cell Death Differ. 2014, 21, 845-853. [CrossRef] [PubMed]

246. Cabello, J.; Neukomm, L.J.; Günesdogan, U.; Burkart, K.; Charette, S.J.; Lochnit, G.; Hengartner, M.O.; Schnabel, R. The Wnt pathway controls cell death engulfment, spindle orientation, and migration through CED-10/Rac. PLoS Biol. 2010, 8, e1000297. [CrossRef] [PubMed]

247. Klinkert, K.; Echard, A. Rab35 GTPase: A Central Regulator of Phosphoinositides and F-actin in Endocytic Recycling and Beyond. Traffic 2016, 17, 1063-1077. [CrossRef] [PubMed]

248. Haley, R.; Wang, Y.; Zhou, Z. The small GTPase RAB-35 defines a third pathway that is required for the recognition and degradation of apoptotic cells. PLoS Genet. 2018, 14, e1007558. [CrossRef]

249. Kawane, K.; Ohtani, M.; Miwa, K.; Kizawa, T.; Kanbara, Y.; Yoshioka, Y.; Yoshikawa, H.; Nagata, S. Chronic polyarthritis caused by mammalian DNA that escapes from degradation in macrophages. Nature 2006, 443, 998-1002. [CrossRef] [PubMed]

250. Yu, H.; Lai, H.-J.; Lin, T.-W.; Chen, C.-S.; Lo, S.J. Loss of DNase II function in the gonad is associated with a higher expression of antimicrobial genes in Caenorhabditis elegans. Biochem. J. 2015, 470, 145-154. [CrossRef] [PubMed]

251. Mukae, N.; Yokoyama, H.; Yokokura, T.; Sakoyama, Y.; Nagata, S. Activation of the innate immunity in Drosophila by endogenous chromosomal DNA that escaped apoptotic degradation. Genes Dev. 2002, 16, 2662-2671. [CrossRef] [PubMed]

252. Seong, C.-S.; Varela-Ramirez, A.; Aguilera, R.J. DNase II deficiency impairs innate immune function in Drosophila. Cell. Immunol. 2006, 240, 5-13. [CrossRef] [PubMed]

253. Liu, Y.; Sun, J. Detection of Pathogens and Regulation of Immunity by the Caenorhabditis elegans Nervous System. MBio 2021, 12, 1-12. [CrossRef] [PubMed]

254. Sternberg, E.M. Neural regulation of innate immunity: A coordinated nonspecific host response to pathogens. Nat. Rev. Immunol. 2006, 6, 318-328. [CrossRef] [PubMed]

255. Steinman, L. Elaborate interactions between the immune and nervous systems. Nat. Immunol. 2004, 5, 575-581. [CrossRef] [PubMed]

256. Tracey, K.J. The inflammatory reflex. Nature 2002, 420, 853-859. [CrossRef] [PubMed]

257. Giunti, S.; Andersen, N.; Rayes, D.; De Rosa, M.J. Drug discovery: Insights from the invertebrate Caenorhabditis elegans. Pharmacol. Res. Perspect. 2021, 9, e00721. [CrossRef] [PubMed]

258. Dantzer, R. Neuroimmune Interactions: From the Brain to the Immune System and Vice Versa. Physiol. Rev. 2018, 98, 477-504. [CrossRef] [PubMed] 